\title{
The Sphere-Cal Process: Fabrication of Fuel Pellets From Gell Microspheres
}

\author{
S. M. Tiegs \\ P. A. Haas \\ R. D. Spence
}

MIR

\section{OAK RIDGE NATIONAL LABORATORY}

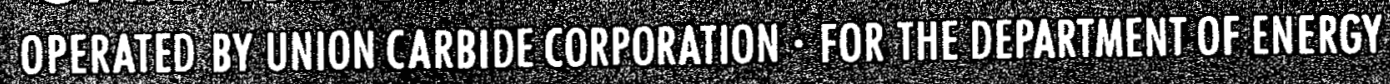




\section{DISCLAIMER}

This report was prepared as an account of work sponsored by an agency of the United States Government. Neither the United States Government nor any agency Thereof, nor any of their employees, makes any warranty, express or implied, or assumes any legal liability or responsibility for the accuracy, completeness, or usefulness of any information, apparatus, product, or process disclosed, or represents that its use would not infringe privately owned rights. Reference herein to any specific commercial product, process, or service by trade name, trademark, manufacturer, or otherwise does not necessarily constitute or imply its endorsement, recommendation, or favoring by the United States Government or any agency thereof. The views and opinions of authors expressed herein do not necessarily state or reflect those of the United States Government or any agency thereof. 


\section{DISCLAIMER}

Portions of this document may be illegible in electronic image products. Images are produced from the best available original document. 
ORNL/TM-6906

Distribution

Category

UC-77, $-78,-79 b$

\author{
Contract No. W-7405-eng-26 \\ METALS AND CERAMICS DIVISION \\ CHEMICAL TECHNOLOGY DIVISION
}

Consolidated Fuel Recycle Program - Refabrication

Gel Sphere Fuel Development - Task 100

THE SPHERE-CAL PROCESS: FABRICATION OF FUEL PELLETS FROM GEL MICROSPHERES

S. M. Tiegs, P. A. Haas, and R. D. Spence

Date Published: September 1979

NOTICE This document contains information of a preliminary nature. It is subject to revision or correction and therefore does not represent a final report.

Research sponsored by the Nuclear Power Development Division, U.S. Department of Energy under Contract W-7405-eng-26 with the Union Carbide Corporation and Purchase Order 64357AG from Battelle Pacific Northwest Laboratories.

\author{
OAK RIDGE NATIONAL LABORATORY \\ Oak Ridge, Tennessee 37830 \\ operated by \\ UNION CARBIDE CORPORATION \\ $f$ or the \\ DEPARTMENT OF ENERGY
}

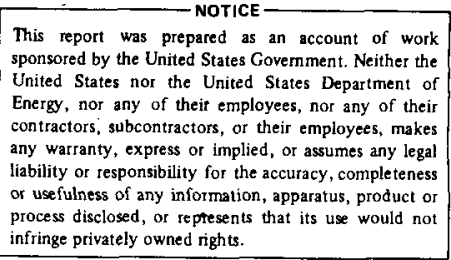

sponsored by the United States $C$ an acront Neither the

United States nor the United States Department of

contractors subco

any warranty, express or implied, or assumes any legal

process disclosed, or sepresents that its use would not 
CONTENTS

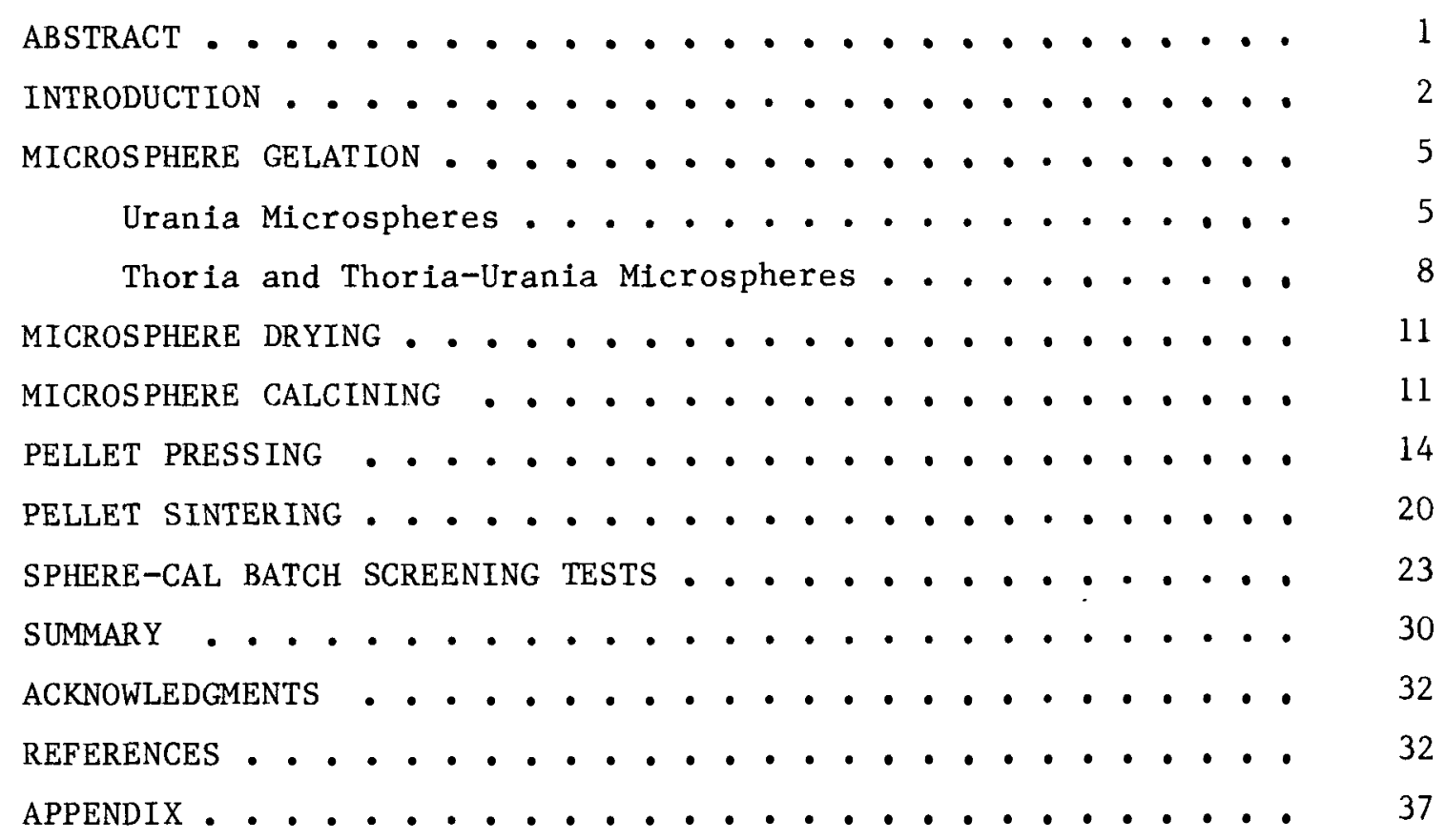




\section{THE SPHERE-CAL PROCESS: FABRICATION OF FUEL PELLETS}

FROM GEL MICROSPHERES

S. M. Tiegs, P. A. Haas, * and R. D. Spence*

\section{ABSTRACT}

The sphere-cal process uses ge1-derived microspheres as feed material for fuel pellet fabrication. Microspheres, because of their free-flowing and dust-free nature, are improved pellet press feed over conventional powder-derived material. The basic sphere-cal process consists of microsphere gelation, drying, and calcining followed by pellet pressing and sintering. We studied each of these process steps to try to determine the important parameters for the production of high quality $\mathrm{UO}_{2}$, $\mathrm{ThO}_{2}$, and $(\mathrm{Th}, \mathrm{U}) \mathrm{O}_{2}$ fuel pellets.

We conducted a statistical experiment to study various microsphere calcining temperatures, forming pressures, and pellet sintering rates. The results were used to select parameters for a standard pellet fabrication screening test, which was a modified ASTM sinterability test procedure. Pellets were fabricated from batches of microspheres produced by using various gelation and drying conditions. Urania microspheres were formed by internal gelation, and thoria and mixed thoriaurania spheres were produced by either internal or external gelation.

From results of the statistical experiment, we determined that $\mathrm{UO}_{2}$ sintered pellet densities increase both with decreasing calcination temperature $\left(1000-600^{\circ} \mathrm{C}\right)$ and with decreasing forming pressure (414-138 $\mathrm{MPa})$. Thermogravimetric analysis results indicate that a minimum calcination temperature of $600^{\circ} \mathrm{C}$ is necessary for complete reduction of the $\mathrm{UO}_{3}$ gel microspheres to $\mathrm{UO}_{2}$. Batch screening test results suggest that use of minimum gel aging, fine-sized microspheres $(50-400 \mu \mathrm{m})$, and fast drying (warm air or oven) will produce the highest quality $\mathrm{UO}_{2}$ pellets. Thoria and thoria-urania microspheres produced by internal gelation or by external gelation (KFA method) were hard and compacted poorly, resulting in pellets with a remnant sphere structure. However, thoria-urania microspheres produced by the SNAM external gelation process were softer, resulting in more homogeneous pellets.

Development work to date has shown that the sphere-cal process is a promising alternative to conventional fuel pellet fabrication. Excellent pellets with homogeneous microstructures and high densities have been produced from urania microspheres. Thoria-urania microspheres produced by the SNAM external gelation process are also promising pellet press feed material. Future work will be directed toward optimization of the sphere-cal process parameters.

*Chemical Technology Division. 


\section{INTRODUCTION}

An alternative process for fabrication of nuclear fuel pellets is the sphere-cal process. This process uses microspheres rather than powder-derived granules as feed material for pellet pressing. The sphere-cal process has several advantages over conventional pellet fabrication methods.

The sphere-cal process is simpler, requiring fewer steps for pellet fabrication than powder processes. The gel microspheres are inherently free flowing. Therefore, preslugging and granulation, which are necessary for powder to produce free-flowing feed material for automatic pellet presses, may be eliminated. Powder milling, which may cause impurities to be introduced into the fuel material, is unnecessary in the sphere-cal process. Furthermore, powder blending would not be necessary to produce mixed-oxide or diversion resistant fuel pellets. Homogeneous heavy metal loadings and uniform spikant dispersion would be more easily attained by the sphere-cal process since mixed nitrate ślutions are used for gel microsphere formation. Pellet centerless grinding may also be eliminated as a result of the more uniform die loading and sintering characteristics of the gel-derived microspheres, which may permit sintering to size.

The sphere-cal process is readily adaptable to remote processing while producing the conventional pellet fuel form. It is especially suited for fuel refabrication since gel microspheres are produced from nitrate solutions. Because the microspheres are free flowing, they are suitable for pneumatic transport. Material holdup problems would be reduced by the use of microspheres rather than powder. Therefore, material accountability and safeguards operations would be improved. Since the gel microspheres are relatively dust free, the spread and buildup of contamination would be minimized. This would reduce both personnel radiation exposure and equipment decontamination times.

Our development work is ongoing to produce urania, thoria, and mixed thoria-urania fuel pellets by the sphere-cal process. The basic sphere-cal process is shown in Fig. 1. First, microspheres are produced 
ORNL-DWG 79-9013

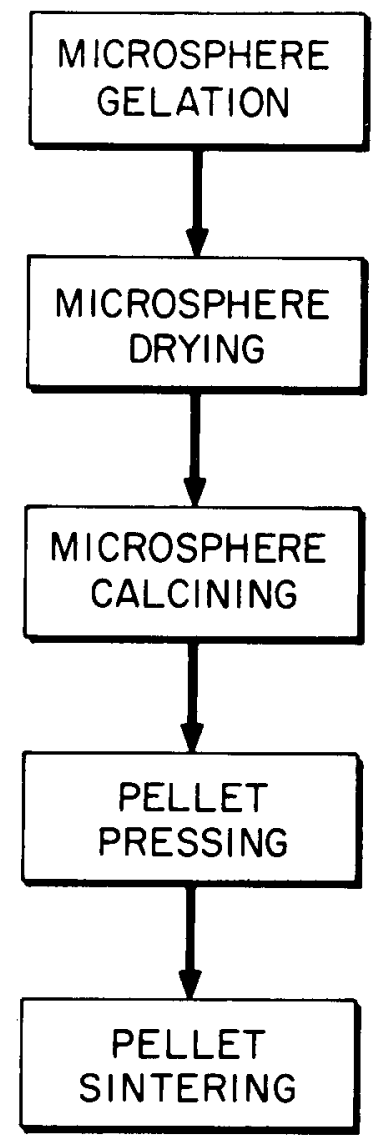

Fig. 1. Sphere-Cal Process.

by chemical gelation - internal gelation for urania microspheres and either internal or external gelation for thoria and mixed thoria-urania microspheres. The microspheres are dried and then calcined to remove water and organics remaining after gelation. During calcination the uranium oxide, which is in the form of $\mathrm{UO}_{3}$, is reduced by use of mixed argon-hydrogen. The calcined microspheres are then cold pressed to form pellets. The pellets are sintered in a reducing atmosphere to produce the sphere-cal products $-\mathrm{UO}_{2}, \mathrm{ThO}_{2}$, or mixed $(\mathrm{Th}, \mathrm{U}) \mathrm{O}_{2}$ fuel pellets. The sphere-cal fuel forms (dried microspheres, calcined microspheres, as-pressed pellets, and sintered pellets) are shown in Fig. 2. Each of the sphere-cal processes will be described in detail in the following sections together with results of our development work to date. 


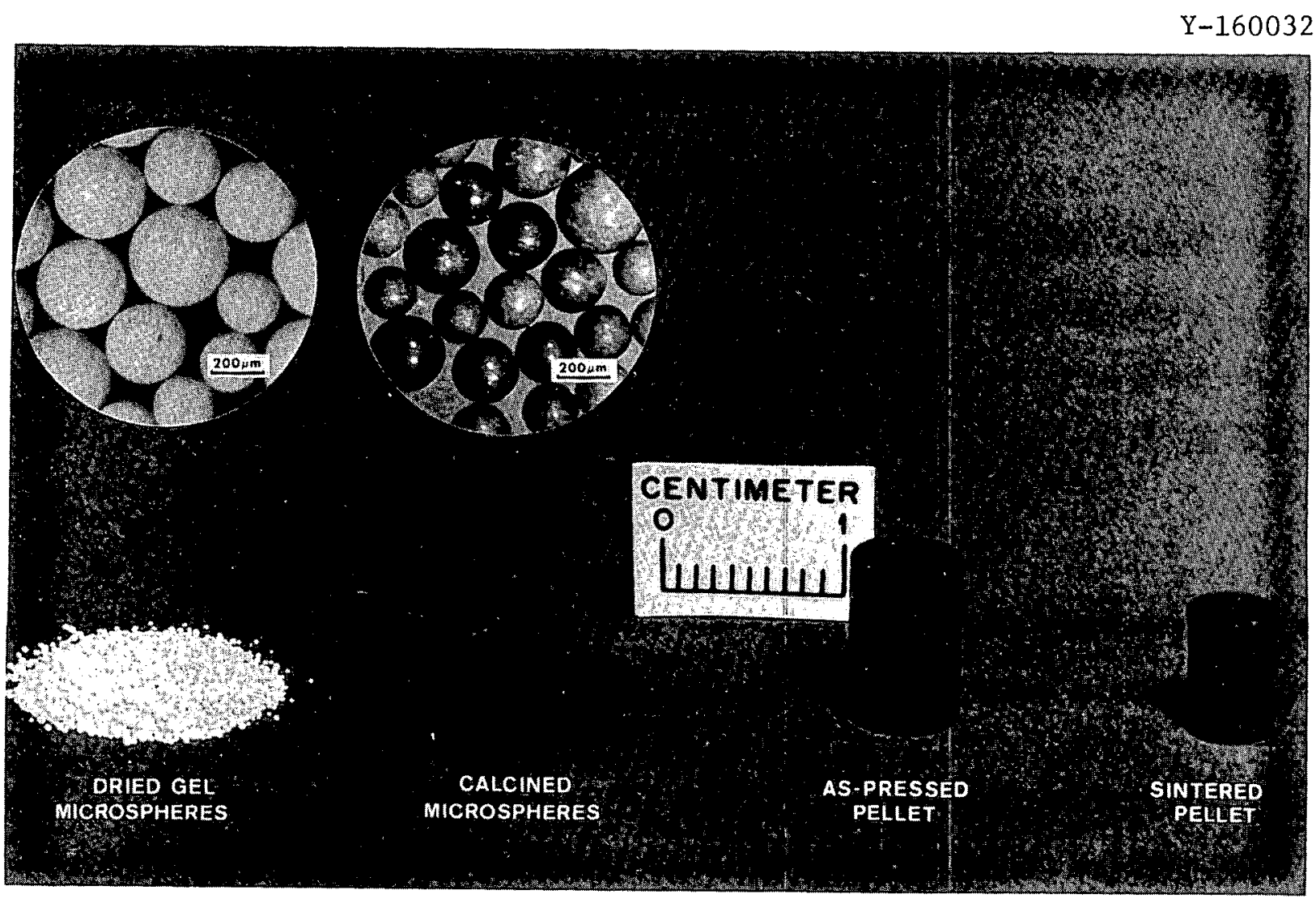

Fig. 2. Fuel Forms During the Sphere-Cal Process.

Previous development work in this area has been mainly concentrated on the use of sol-gel derived powders or shards for pellet fabrication. $1-4$ However, a brief development program was conducted on fabrication of $(\mathrm{U}, \mathrm{Pu})_{2}$ pellets from microspheres formed by water extraction. ${ }^{5}$ Relatively low-density pellets with a remnant microsphere structure were produced during this program. Presently, the Italians at CNEN*6 are developing a process to utilize microspheres formed by the SNAMt external gelation method for the fabrication of $(\mathrm{U}, \mathrm{Pu})_{2}$ fuel pellets.

*Comitato Nazionale per L'energia Nucleare, Casaccia, Roma, Italy. †SNAM Progetti S.p.A., Italy. 


\section{MICROSPHERE GELATION}

Microspheres that were evaluated for use as sphere-cal process feed material were produced by several gelation methods. Urania microspheres were formed by internal gelation; thoria spheres were produced by external gelation, and mixed thoria-urania spheres were fabricated by either internal or external gelation.

Initially, flowsheets and procedures developed for production of microspheres for the sphere-pac ${ }^{7-9}$ process were applied to prepare gel spheres for the sphere-cal process. Based on results from sphere-cal batch screening tests, the gel sphere preparation conditions have been modified to improve the gel sphere properties as they relate to pellet fabrication. The basic gelation flowsheets used for the preparation of microspheres for the sphere-cal process will be described in the following sections.

Urania Microspheres

The microspheres used for the production of $\mathrm{UO}_{2}$ fuel pellets were formed by internal gelation (modified KEMA* process).10,11 A watersoluble chemical that releases ammonia when heated is used to precipitate the heavy metal to gel spheres internally. Since the ammonia donor and the heavy metal ions are dissolved in the same solution, the gelation occurs rapidly and uniformly throughout the drop.

The flowsheet for internal gelation is shown in Fig. 3. First, a broth is prepared, which contains an acid-deficient solution of the heavy metal (in this case uranium) with urea added and an ammonia donor solution of hexamethylenetetramine [HMTA, $\left.\left(\mathrm{CH}_{2}\right)_{6} \mathrm{~N}_{4}\right]$. The broth is pumped through a dispersion device that forms drops, which are then gelled in a hot organic medium. The gelation reaction is

$$
2 \mathrm{UO}_{2}\left(\mathrm{NO}_{3}\right)_{2}+\left(\mathrm{CH}_{2}\right)_{6} \mathrm{~N}_{4}+(8+2 x) \mathrm{H}_{2} \mathrm{O} \underset{\rightarrow}{\Delta} 4 \mathrm{NH}_{4} \mathrm{NO}_{3}+6 \mathrm{CH}_{2} \mathrm{O}+2 \mathrm{UO}_{3}\left(\mathrm{H}_{2} \mathrm{O}\right)_{x} \cdot
$$

\footnotetext{
*Keuring van Elecrotechnische Materialen, Arnhem, Netherlands.
} 
ORNL-DWG 79-9259

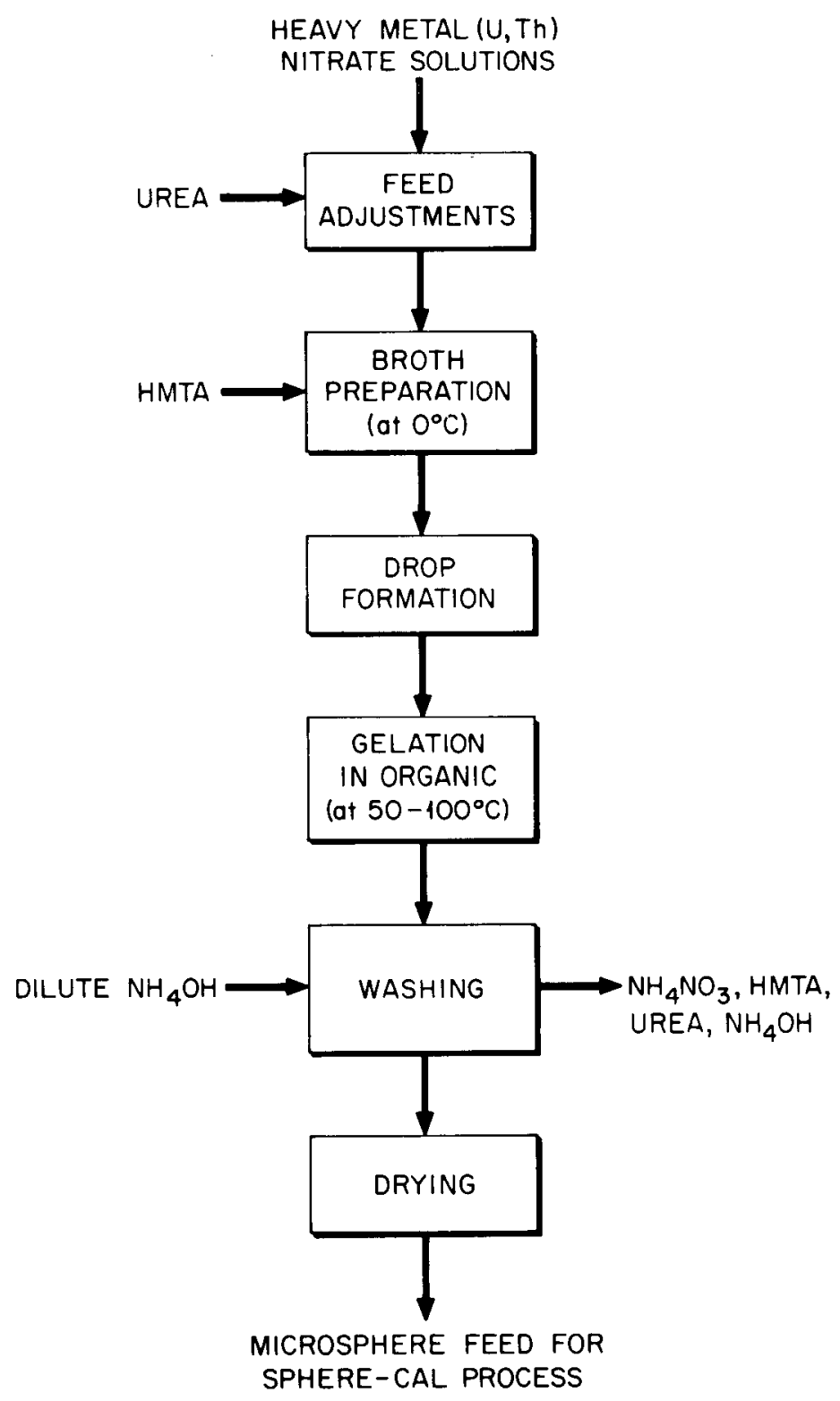

Fig. 3. Microsphere Preparation by Internal Gelation.

The organic medium is then removed by an air purge or with a suitable solvent (e.g., isopropyl alcohol), and the spheres are washed with dilute aqueous ammonia $\left(\mathrm{NH}_{4} \mathrm{OH}\right)$ to remove HMTA, urea, and ammonium nitrate $\left(\mathrm{NH}_{4} \mathrm{NO}_{3}\right)$. With proper gelation conditons the spheres are opaque and have a large enough crystallite size so that the urea, HMTA, and $\mathrm{NH}_{4} \mathrm{NO}_{3}$ can be easily washed out. 
Standard broth preparation includes the following mole ratios of the components: $1.5-1.7 \mathrm{NO}_{3}-/ \mathrm{U}, 1.1-1.3 \mathrm{HMTA} / \mathrm{U}$, and 1.25 urea/U. The broth is held at -5 to $0^{\circ} \mathrm{C}$ to reduce the decompositon rate of HMTA and thus prevent premature gelation. Also, urea is added to complex the uranyl ions $\left(\mathrm{UO}_{2}{ }^{2+}\right)$ to help prevent them from reacting with the slowly decomposing HMTA.

The chilled broth is then pumped to a disperser, which forms drops of the required size in the hot immiscible organic liquid. Microspheres were formed by two different methods for use as sphere-cal feed material. Coarse spheres, about $600 \mu \mathrm{m}$ when dried, were formed by using a vibrated nozzle, which produces a narrow range of sphere sizes. Fine spheres, about $100 \mu \mathrm{m}$ when dried, were formed in a turbulent shear nozzle to increase the sphere production rate. This produces spheres with a much wider range of sizes. From preliminary results it appears that a dried gel sphere of about $200 \mu \mathrm{m}$ is optimum, and microspheres in this size range may be produced in either the coarse or fines forming equipment.

In the hot liquid the rate of HMTA decomposition overcomes the urea-uranyl ion complex and causes precipitation of ammonium diuranate, resulting in gelation of the drops. Two different organic liquids, 2-ethy1-1-hexanol (2-EH) and trichloroethylene (TCE), were used during the production of urania spheres for sphere-cal feed. Organic temperatures between 45 and $88^{\circ} \mathrm{C}$ were used for gelation.

Several urania batches were produced by a modified internal gelation process - the "H" process. The broth was prepared with the following mole ratios of the components: $2.2 \mathrm{NO}_{3}^{-} / \mathrm{U}, 0.5 \mathrm{NH}_{4}^{+} / \mathrm{U}, 2.0 \mathrm{HMTA} / \mathrm{U}$, 2.0 urea/U. Higher dried sphere bulk densities, which are desirable for improved compaction ratios, were obtained by this process. However, the microspheres were much harder and compacted poorly. Results of spherecal tests that used material formed by the "H" process will be discussed in a later section of this report.

Urania microspheres used as sphere-cal feed were produced in both lab scale equipment (with batch preparation of broth and typically 0.1 to $0.6 \mathrm{~kg}$ product per test) and engineering scale equipment (with continuous preparation of broth and a capacity to produce larger quantities of material per test). 
Thoria and Thoria-Urania Microspheres

Thoria-urania microspheres (about 12-25\% U) used as sphere-cal feed material were produced by either internal or external gelation. One batch of pure thoria spheres produced by external gelation was also tested to determine its suitability as feed for the sphere-cal process.

The internally gelled thoria-urania spheres were formed according to the same flowsheet (see Fig. 3) as the internally gelled urania spheres. Best results were obtained when the broth was prepared from a solution of thorium nitrate mixed with powdered $\mathrm{UO}_{3}$. The thoriumuranium feed was prepared with the following ratios: $\mathrm{HMTA} / \mathrm{NO}_{3}^{-}=0.7$, urea $/ U=2.0, \mathrm{NO}_{3}-/(\mathrm{Th}+\mathrm{U})=3.0$. Microspheres (about $300 \mu \mathrm{m}$ when dried) containing approximately $25 \%$ uranium were produced by this method for use in sphere-cal testing.

Mixed thoria-urania microspheres were formed according to two different external gelation flowsheets - the Italian-SNAM process 12 and the German KFA*-Jülich process. 13 Thoria microspheres were also produced by the KFA external gelation process.

The original external gelation method was the Italian-SNAM process, which is a gel-supported precipitation process. The flowsheet for this process is shown in Fig. 4. To form microspheres by the SNAM process, a water-soluble organic polymer is added to the heavy metal solution. This polymer supports the particle spherical shape during gelation. Besides the polymer a modifier is added to protect the polymer from acid attack and to adjust the viscosity.

The spheres are formed by dripping the broth from a capillary or by flowing the broth through a vibrating nozzle into air. Spherical drops form from the effect of surface tension before exposure to the precipitation chemical. Deformation may occur as the spheres impinge upon the precipitating chemical medium. To prevent this the droplet is exposed to ammonia gas to strengthen the surface of the sphere. The droplet is then completely gelled in a solution of ammonium hydroxide $\left(\mathrm{NH}_{4} \mathrm{OH}\right)$.

*Kernforschungsanlage, Jülich, West Germany. 


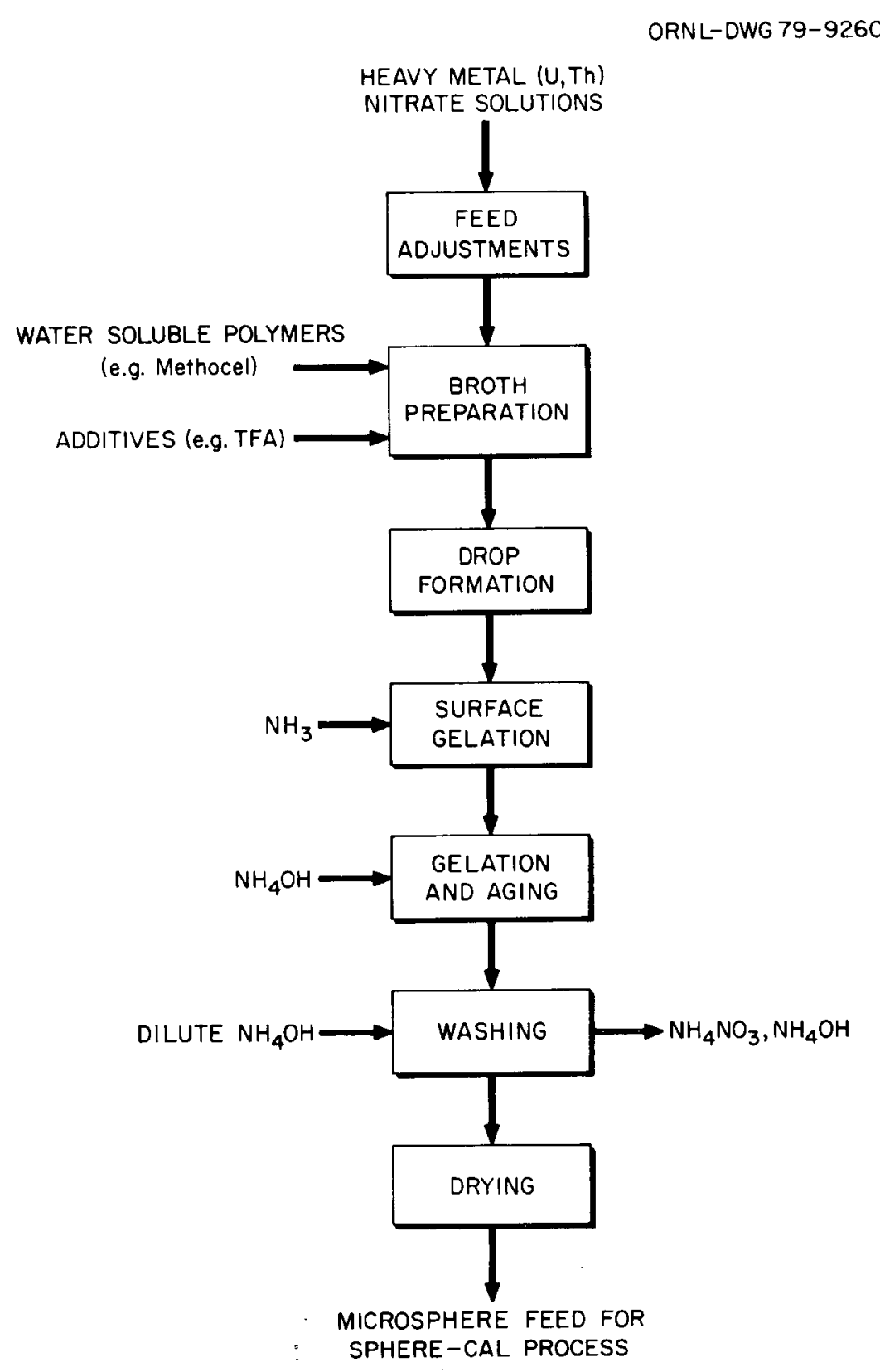

Fig. 4. Microsphere Preparation by External Gelation.

The spheres are aged in the ammonium hydroxide until gelation has been completed through to their centers. They are then washed with dilute ammonium hydroxide. Salts such as ammonium nitrate, which may cause sphere cracking during drying, are removed during the washing process. 
To produce mixed thoria-urania microspheres by the SNAM process for sphere-cal testing, a thorium-containing sol and a uranium-bearing solution were mixed. The thorium-containing sol was prepared from a thorium nitrate $\left[\mathrm{Th}\left(\mathrm{NO}_{3}\right)_{4}\right]$ solution preneutralized approximately $75 \%$ to $\mathrm{Th}(\mathrm{OH})_{4}$ by $\mathrm{NH}_{4} \mathrm{OH}$ addition. The resulting sol was then mixed with a hydroxypropyl methylcellulose (Methocel) polymer (about $7 \mathrm{~kg} / \mathrm{m}^{3}$ ). The sol had a final heavy metal concentration of $0.7 \mathrm{MTh}$. The uraniumbearing solution was prepared from a uranyl nitrate solution with no pretreatment necessary. A Methocel polymer and a tetrahydrofurfuryl alcohol (TFA) modifier were mixed with the uranyl nitrate. The final uranium solution was $0.7 \mathrm{MU}, 20 \% \mathrm{TFA}$, and $7 \mathrm{~kg} / \mathrm{m}^{3}$ Methocel. Spheres containing about $20 \% \mathrm{U}$ with a dried size about $700 \mu \mathrm{m}$ in diameter were produced from a mixture of these two solutions. The spheres were formed with a vibrating nozzle, although the broth was fairly viscous. These spheres were promising sphere-cal material because of their soft gel structure, as will be discussed in a later section of this report.

Thoria-urania microspheres produced by the KFA-Jülich external gelation process were formed from a mixture of thorium nitrate and uranyl nitrate. This heavy metal solution was neutralized with ammonia gas to a $\mathrm{pH}$ end point of about 4.0. Attempts to produce a sol with greater than $15 \% \mathrm{U}$ were unsuccessful. No polymer or other additives were used in the KFA process.

The spheres were formed from the resulting sol by a method similar to the SNAM process. The sol was pumped through a vibrating nozzle to form spheres in air. The spheres were surface hardened with ammonia gas and gelled in a mixture of ammonium hydroxide and ammonium nitrate. Mixed thoria-urania microspheres containing about $12 \% \mathrm{U}$ (about $700 \mu \mathrm{m}$ in diameter when dried) were produced by the KFA process. Thoria microspheres (about $700 \mu \mathrm{m}$ in diameter when dried) for sphere-cal pelletizing tests were also produced by the KFA external gelation process with use of a thorium nitrate sol produced with ammonia gas neutralization.

Thoria and thoria-urania microspheres produced by internal gelation or by KFA-Jülich external gelation processes proved too hard to easily compact into pellets and therefore were not as promising as spheres 
produced by the SNAM external gelation process for use as sphere-cal feed material. These results will be discussed in more detail in a later section of this report.

\section{MICROSPHERE DRYING}

The microspheres were dried following gelation and washing to remove residual water and low-boiling organics. Drying must be properly controlled so that cracks or other microsphere defects are not produced. The rate of drying must be limited to allow the water time to escape from the spheres without producing cracks. Dried spheres with a high bulk density are desirable for pellet pressing to minimize the compaction ratio.

We have tested several drying techniques: drying by using a vacuum to pull room temperature (RT) air through the wet gel beads and drying in an oven at $220^{\circ} \mathrm{C}$. In the latter case the wet gel beads were placed in a container with a restricted opening and were therefore dried in a humid or steam atmosphere. To increase the dried sphere densities, we developed a warm air drying technique. Air was heated to $60^{\circ} \mathrm{C}$ before being passed through the bed of gel spheres. By this method internally gelled urania sphere densities were increased about $25 \%$ over spheres dried by conventional procedures.

\section{MICROS PHERE CALCINING}

Calcincation of the gel microspheres is necessary for controlled release of water and residual organics that remain following microsphere gelation and drying. It is also necessary, in the case of uraniumcontaining material, for reduction of the oxygen-to-metal ratio ( $0 / M)$ before pelletizing. Therefore, an inert gas-hydrogen mixture is used during calcination.

During preliminary experiments to determine a satisfactory calcination temperature, urania microspheres (batch GT-371) were calcined at 400,600 , and $800^{\circ} \mathrm{C}$ in $\mathrm{Ar}-4 \% \mathrm{H}_{2}$. We used a heating schedule of $100^{\circ} \mathrm{C} / \mathrm{h}$ 
with a 4-h hold time at temperature. Pellets were cold pressed at 138 to $414 \mathrm{MPa}(20,000-60,000 \mathrm{psi})$ and sintered at $1450^{\circ} \mathrm{C}$ in $\mathrm{Ar}-4 \% \mathrm{H}_{2}$.

Excellent pellets with homogeneous microstructures were fabricated from the microspheres calcined at $600^{\circ} \mathrm{C}$. Pellet densities, measured by mercury pycnometry, were as high as $95.2 \%$ of theoretical density (T.D.). Al1 the pellets formed from microspheres that were calcined at $400^{\circ} \mathrm{C}$ cracked apart during sintering, and the pellets pressed from the $800^{\circ} \mathrm{C}$ calcined spheres were lower in density.

Thermogravimetric analysis (TGA) of a batch of urania microspheres revealed that $600^{\circ} \mathrm{C}$ was a good calcination temperature. A sample of dried microspheres was heated to $900^{\circ} \mathrm{C}$ in $\mathrm{Ar}-4 \% \mathrm{H}_{2}$, while weight loss and water evolution were continuously monitored. Reduction of the material appeared to be complete with stabilized weight loss and water evolution by $550^{\circ} \mathrm{C}$, as shown in Fig. 5.

\section{ORNL-DWG 78-19381R2}

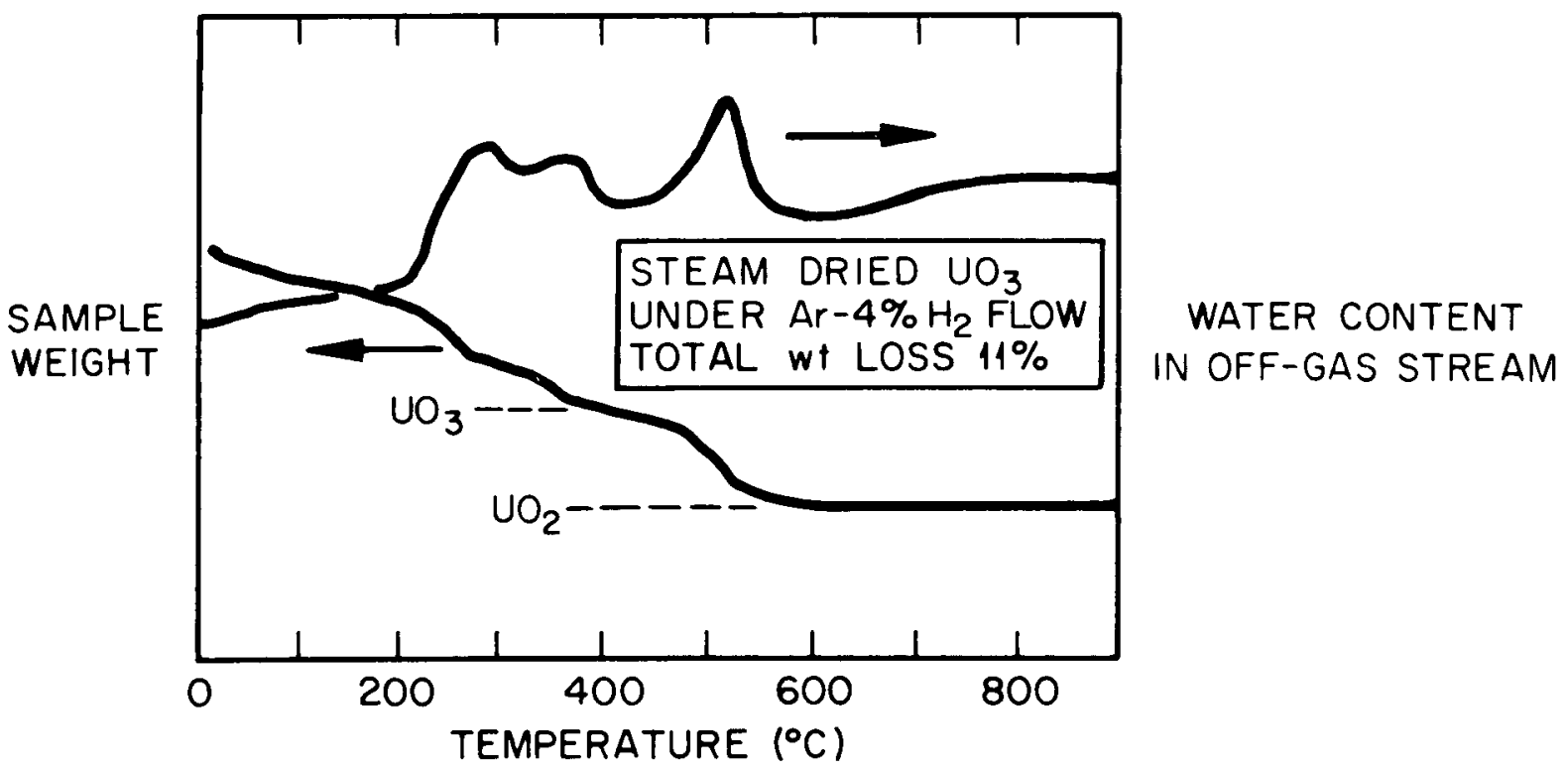

Fig. 5. Weight Loss and Water Evolution During Thermogravimetric Analysis of Urania Gel Microspheres. 
The $0 / \mathrm{M}$ ratios of two batches of urania microspheres (GT-371 and IGT-60) were measured following calcination runs made at various temperatures $\left(400-1000^{\circ} \mathrm{C}\right)$. Our results, that is, $0 / \mathrm{M}$ ratio values from 2.2 to 2.7, were unexpected. Therefore, we concluded that the microspheres had oxidized upon exposure to room air following calcination. A sample of urania microspheres (IGT-61B) calcined at $620^{\circ} \mathrm{C}$ was removed under inert atmosphere protection. An $0 / \mathrm{M}$ ratio of 2.0 was measured for this sample, showing that the reduction reaction was complete at this calcination temperature. This sample was then exposed to room air, and it reoxidized. The $0 / M$ ratio was 2.40 after $10 \mathrm{~min}$ in air and 2.48 after $1 \mathrm{~h}$.

As shown in Fig. 6 the $0 / M$ ratio decreases with increasing calcination temperature. It appears that increased calcination temperature reduces the potential for microsphere reoxidation. This finding is consistent with results showing that the sinterability of the microspheres is reduced as calcination temperature increases. These results will be discussed in the pellet sintering section of this report.

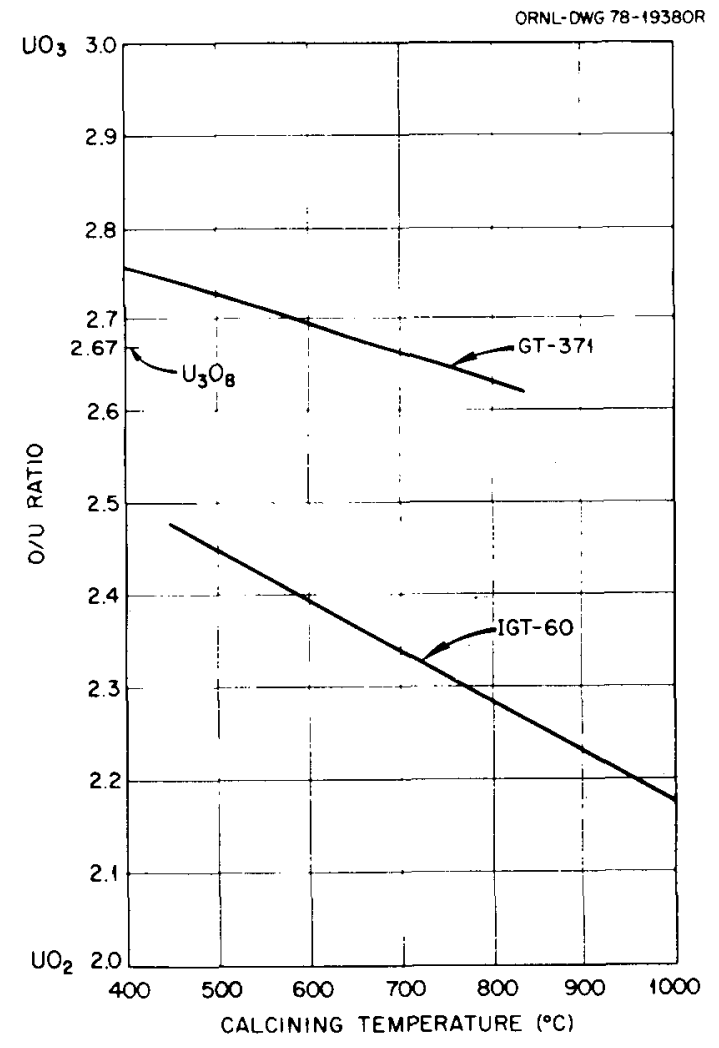

Fig. 6. The O/M Ratio of Calcined Urania Microspheres Following Room Air Exposure for Severa1 Days (Batches GT-371, About 250-um spheres and IGT-60, About 800- $\mu \mathrm{m}$ spheres). 
We have initiated development work to determine a method to increase the oxidation resistance of the microspheres following calcination without appreciably reducing sphere sinterability. Doubling the hold time at temperature from 4 to $8 \mathrm{~h}$ during calcination at $600^{\circ} \mathrm{C}$ did not appear to stabilize the microspheres. Microspheres calcined at $600^{\circ} \mathrm{C}$ in pure hydrogen appeared to be especially reactive and oxidized completely to $\mathrm{U}_{3} \mathrm{O}_{8}(\mathrm{O} / \mathrm{M}=2.67)$ upon exposure to room air.

Thoria and mixed thoria-urania microspheres were not calcined before pressing since calcining at even low temperatures caused several microsphere batches to become very hard to compact. However, thoria-urania microspheres formed by the SNAM external gelation process have a soft ge1 structure, and our development work is ongoing to optimize the calcination conditions for this material to be used as pellet press feed.

\section{PELLET PRESSING}

Microspheres were cold pressed into cylindrical pellets with a manual hydraulic press and forming pressures from 138 to $414 \mathrm{MPa}(20,000-$ $60,000 \mathrm{psi})$. Dies with two movable punches and diameters from 6.35 to $12.7 \mathrm{~mm}(1 / 4-1 / 2 \mathrm{in}$.) were used. Pellet length to diameter ratios (L/D) were usually between 1 and 2. A solution of stearic acid in acetone was used as a die lubricant. Other pellet lubricants and binders such as Sterotex* and Carbowax $\dagger$ did not appear to be necessary for successful pelletizing.

Calcined urania microspheres deformed readily under pressure to form good compacts. The crushing strength of these microspheres could not be measured since they readily deformed, and a break point could not be easily distinguished. Figure 7 shows a fracture surface of an as-pressed (unsintered) pellet. A polished surface view is shown in Fig. 8. This pellet was fabricated from microspheres (IGT-60) calcined at $1000^{\circ} \mathrm{C}$, which should have greater crushing strength than microspheres calcined

\footnotetext{
*Product of Capitol City Products Company, Division of StokelyVan Camp, Inc., Columbus, Ohio.

†Product of Carbide and Carbon Chemicals Company, Division of Union Carbide Corporation, South Charleston, West Virginia.
} 
ORNL-DWG 79-8108

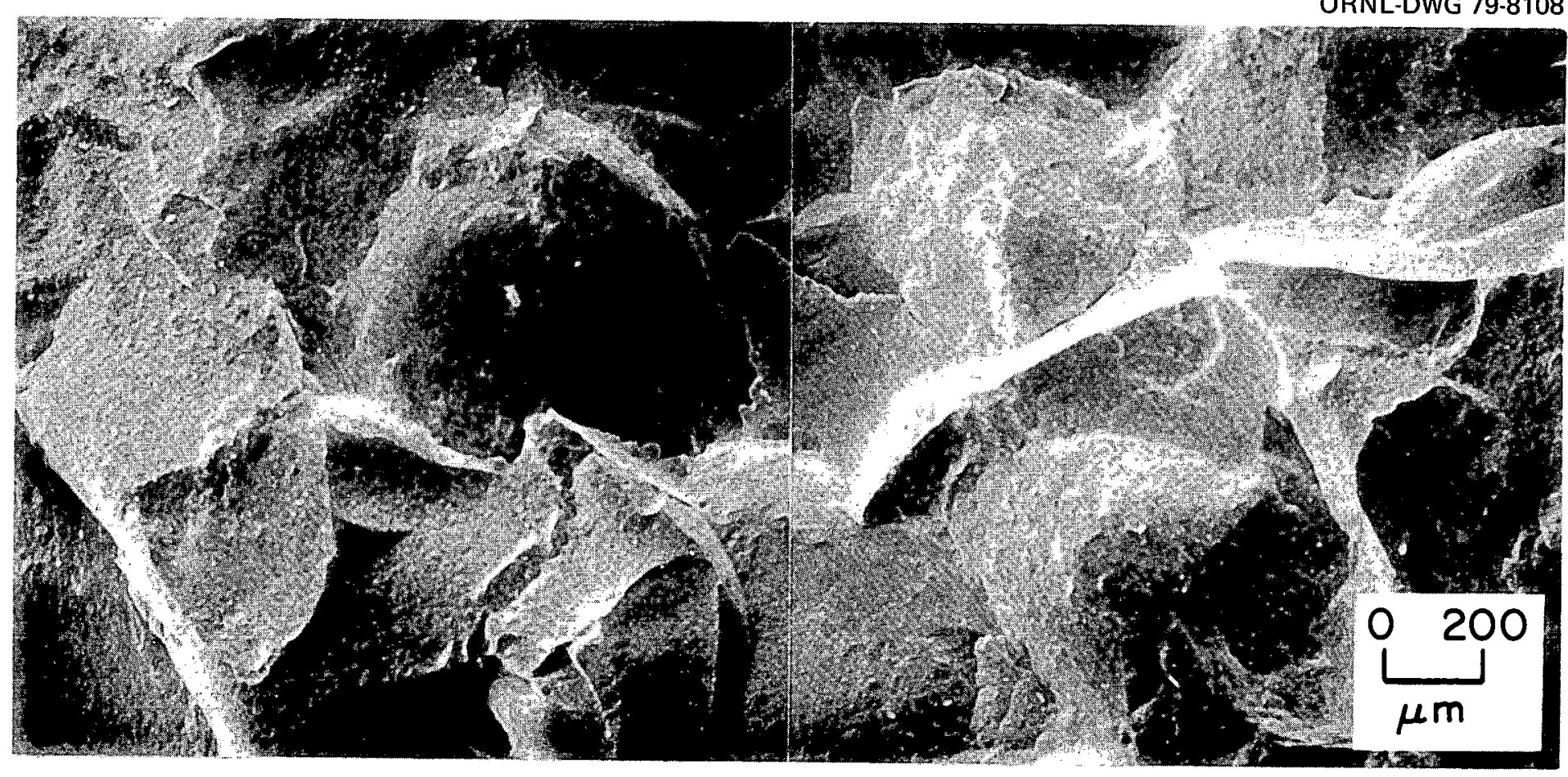

Fig. 7. Fracture Surface of As-Pressed Urania Pellet (Batch IGT-60, About 800- $\mu \mathrm{m}$ Spheres, $1000^{\circ}$ Calcine). 


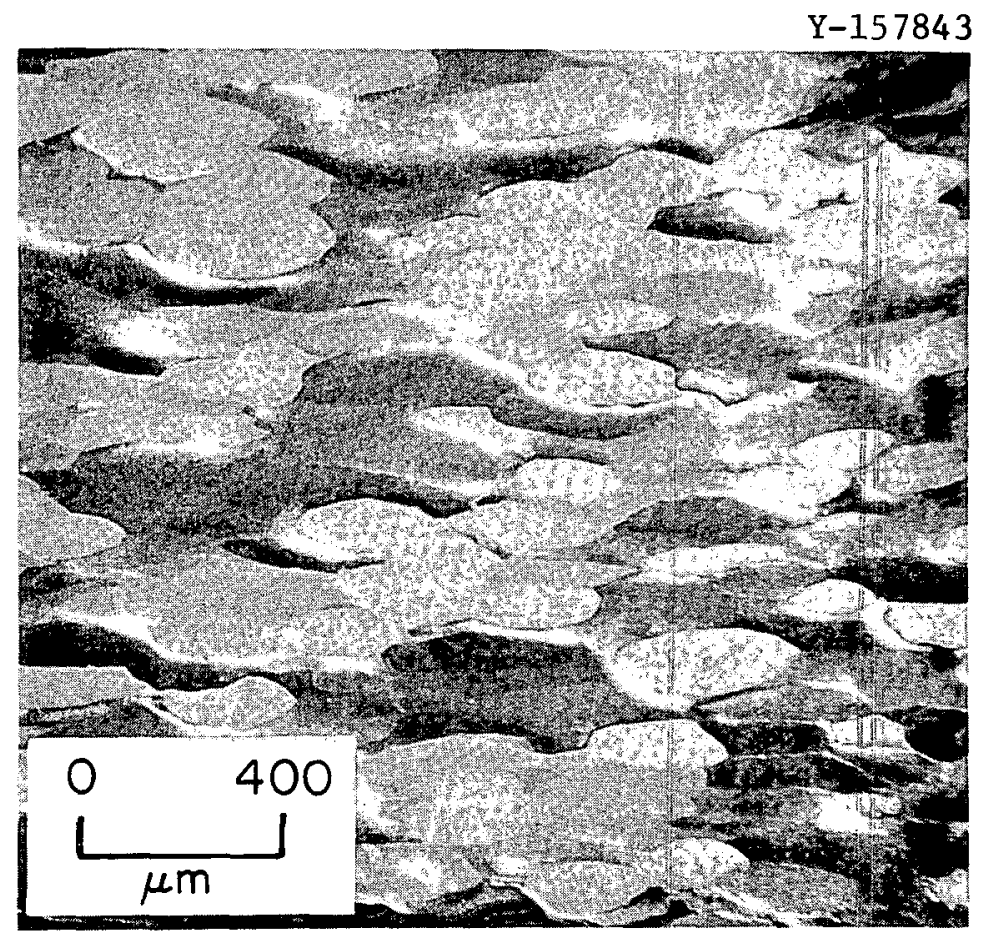

Fig. 8. Polished Section of As-Pressed Urania Pellet (Batch IGT-60, About $800-\mu \mathrm{m}$ Spheres, $1000^{\circ}$ Calcine).

at $600^{\circ} \mathrm{C}$. The forming pressure was $138 \mathrm{MPa}(20,000 \mathrm{psi})$, and the microspheres deformed readily to fill in the voids between spheres. However, most batches of thoria and mixed thoria-urania microspheres were very hard to compact and fractured rather than deforming under pressure. A typical microstructure of a sintered mixed thoriaurania pellet is shown in Fig. 9. Remnants of the original microspheres are clearly visible together with shards from fractured spheres. The mixed thoria-urania spheres were not calcined before pressing since calcining at even low temperatures caused the microspheres to become harder to press. Pellets with this appearance were produced from thoria and mixed thoria-urania microspheres formed by either internal or external gelation (KFA method). Pellets pressed from urania microspheres formed by the "H" process (internal gelation) also had a similar type microstructure. This process appears to produce spheres too hard to be suitable as sphere-cal feed material. 

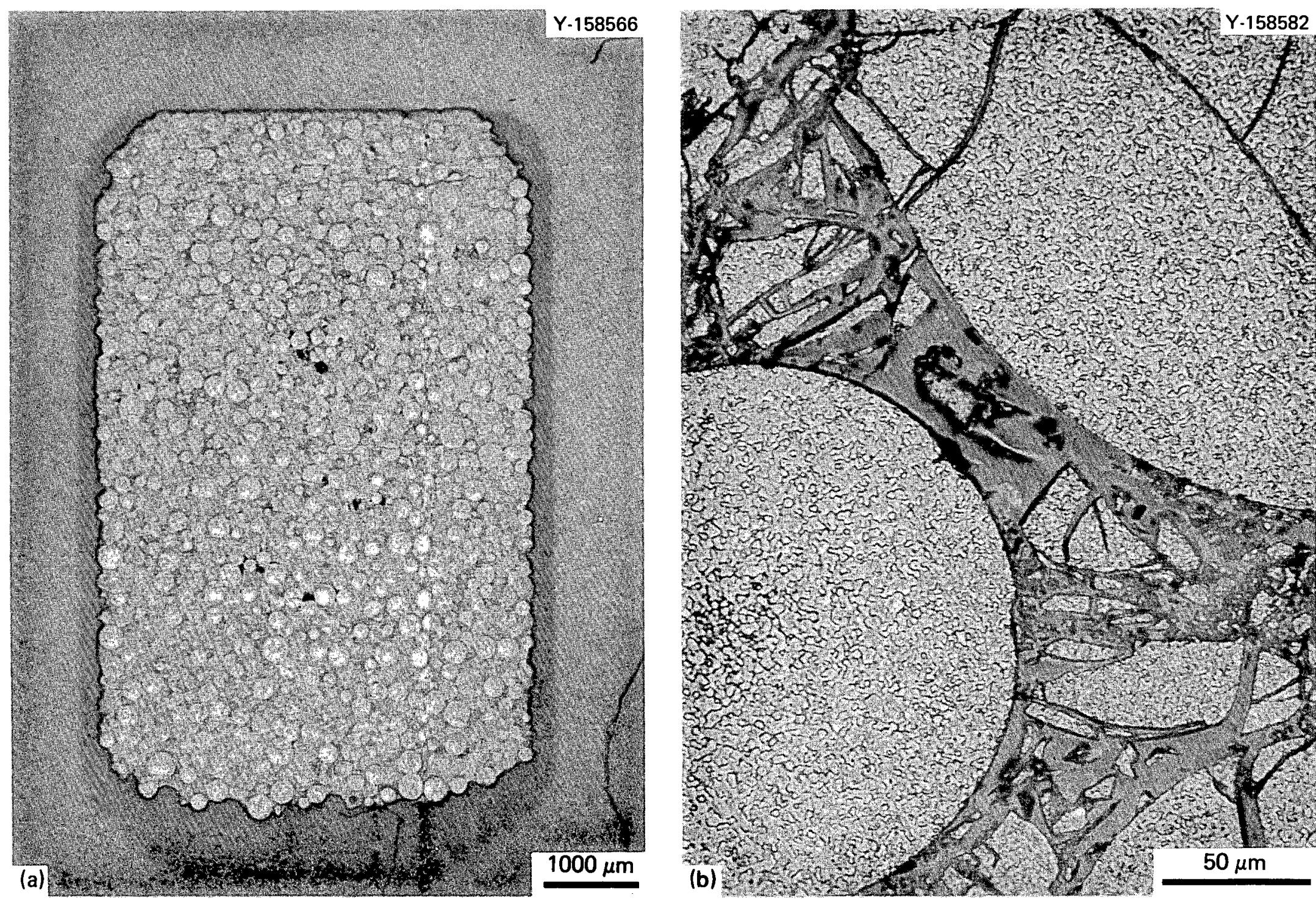

Fig. 9. A (Th,U)O ${ }_{2}$ Pellet with Remnant Microsphere Structure (Batch GT-484, About 300- $\mu \mathrm{m}$ Spheres, Internal Gelation, $\mathrm{Th} / \mathrm{U}=3$ ). (a) As polished. (b) Etched ( $30 \mathrm{H}_{3} \mathrm{PO}_{4}: 1 \mathrm{HF}$ ). 
Thoria-urania microspheres formed by the SNAM external gelation process gave promising results since they have a much softer gel structure. Pellets pressed from SNAM-type microspheres were more homogeneous, and individual sphere remnants were not as visible since the microspheres sintered together better. Our development work is ongoing to optimize the calcination conditions for SNAM-type microspheres to be used as sphere-cal feed material.

We performed a statistical experiment to study various urania microsphere calcining temperatures, forming pressures, and sintering rates. The levels of the variables are shown in Table 1. Results showed that green pellet densities increase with increasing forming pressure, as shown in Fig. 10, and that sintered pellet densities decrease with increasing forming pressure, as shown in Fig. 11. The latter result was unexpected but may possibly be explained by the fact that many pellets in this experiment contained cracks. Pellet feed material had oxidized upon exposure to air following calcining, and therefore, the pellets underwent reduction during sintering. Pellets with higher green density may have been more prone to cracking as a result of the release of trapped water vapor during pellet reduction. 14

Table 1. Statistical Experiment $3^{2} \times 2$ Design

\begin{tabular}{ll}
\hline \multicolumn{1}{c}{ Process Variables } & Levels \\
\hline $\begin{array}{l}\text { Calcining temperature } \\
\left({ }^{\circ} \mathrm{C}\right)\end{array}$ & $600,800,1000$ \\
Forming pressure (MPa) & $138,276,414$ \\
Sintering schedule & (1) $100^{\circ} \mathrm{C} / \mathrm{h}$ to $1450^{\circ} \mathrm{C}$ \\
& (2) $100^{\circ} \mathrm{C} / \mathrm{h}$ to $450^{\circ} \mathrm{C}$ \\
and $300^{\circ} \mathrm{C} / \mathrm{h}$ to \\
$1450^{\circ} \mathrm{C}$
\end{tabular}




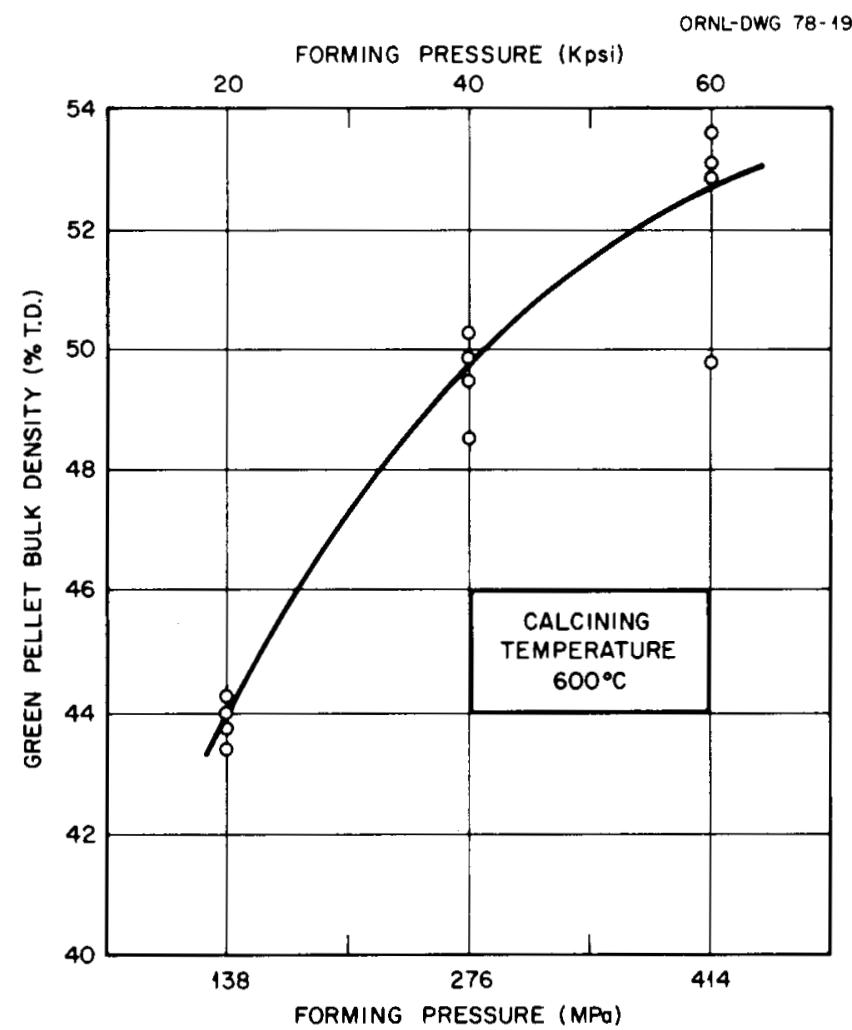

Fig. 10. Green Pellet Densities Increased with Increasing Pressure.

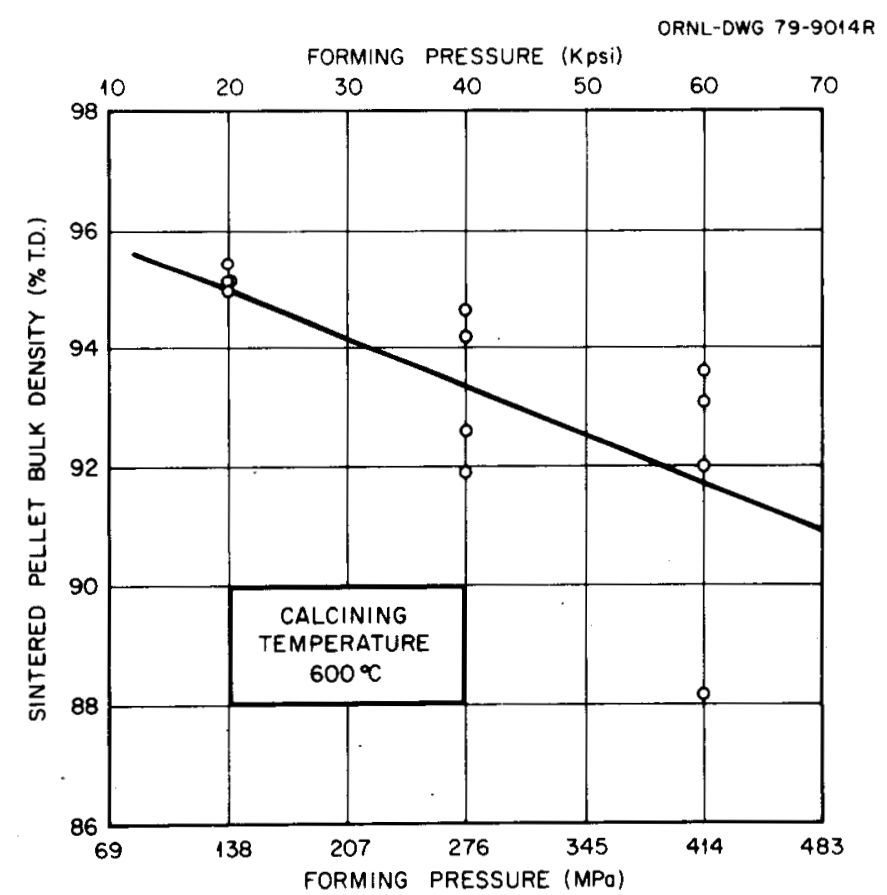

Fig. 11. Sintered Pellet Densities Decreased with Increasing Pressure. 


\section{PELLET SINTERING}

For ease of comparison of the sinterability and quality of various gel microsphere batches, we selected a single sintering schedule. This schedule had been shown 15 to be satisfactory for sintering individual urania, thoria, and thoria-urania microspheres to greater than $99 \%$ T.D. Our schedule (Fig. 12) was a heating rate of $100^{\circ} \mathrm{C} / \mathrm{h}$ to $450^{\circ} \mathrm{C}$ followed by a heating rate of $300^{\circ} \mathrm{C} / \mathrm{h}$ to $1450^{\circ} \mathrm{C}$. The pellets were allowed to soak during a $4-\mathrm{h}$ hold at $1450^{\circ} \mathrm{C}$. Then they were cooled slowly as the furnace cooled to room temperature at a rate of approxinately $100^{\circ} \mathrm{C} / \mathrm{h}$. A reducing atmosphere, $\mathrm{Ar}-4 \% \mathrm{H}_{2}$, was used during the heatup and soak periods, and argon was used during furnace cool-down.

ORNL-DWG 79-9012R

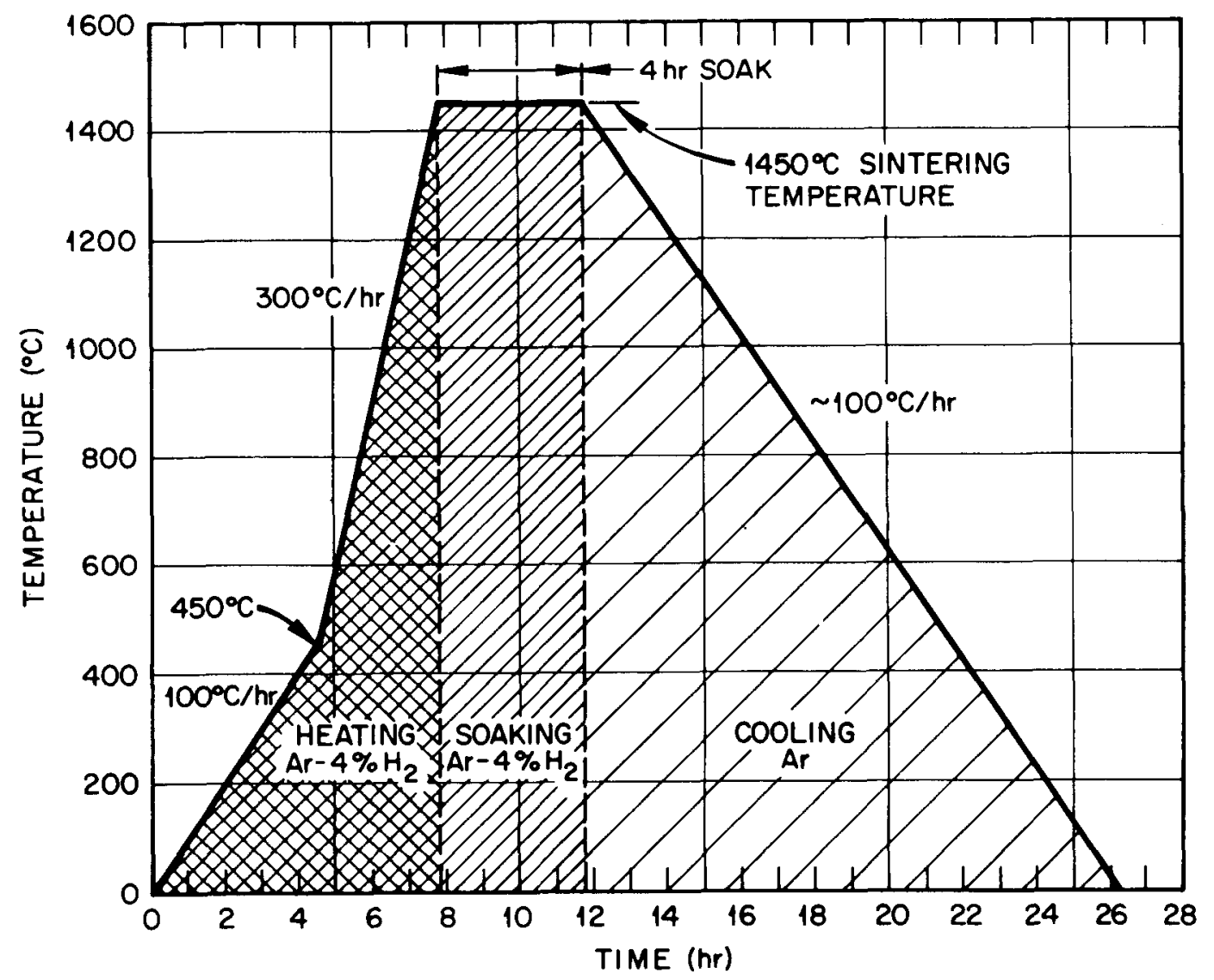

Fig. 12. Sphere-Cal Pellet Sintering Schedule. 
To confirm that this sintering schedule was satisfactory, a slower heating rate was tested in a statistical experiment (see Table 1 ). Half of the urania pellets in the experiment were sintered by using the standard schedule described above, and half were fired with a heating rate of $100^{\circ} \mathrm{C} / \mathrm{h}$ to the sintering temperature of $1450^{\circ} \mathrm{C}$. Results from this experiment were inconclusive since many of the pellets cracked, but little difference was detected between the two sintering schedules.

In the same statistical experiment (to study calcining temperature, forming pressure, and sintering schedule) we determined that the sinterability of urania microspheres was reduced as the calcination temperature increased. Sintered pellet densities decreased with increasing calcination temperature, especially above $800^{\circ} \mathrm{C}$, as shown in Fig. 13. Scanning electron microscope (SEM) micrographs of the fractured surface of a pellet from this experiment, which contained spheres calcined at $1000^{\circ} \mathrm{C}$, are shown in Fig. 14. Individual spheres did not sinter together we11, and cracks between spheres were still present.

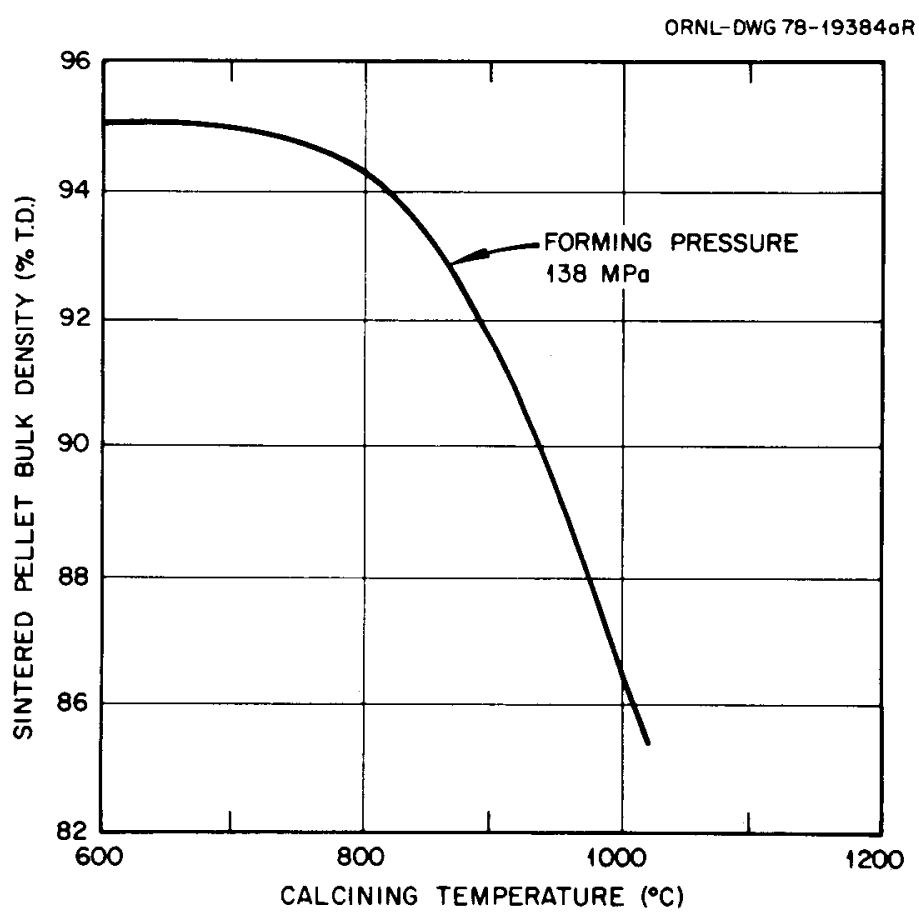

Fig. 13. Sintered Pellet Densities Decreased with Increasing Calcination Temperature. 

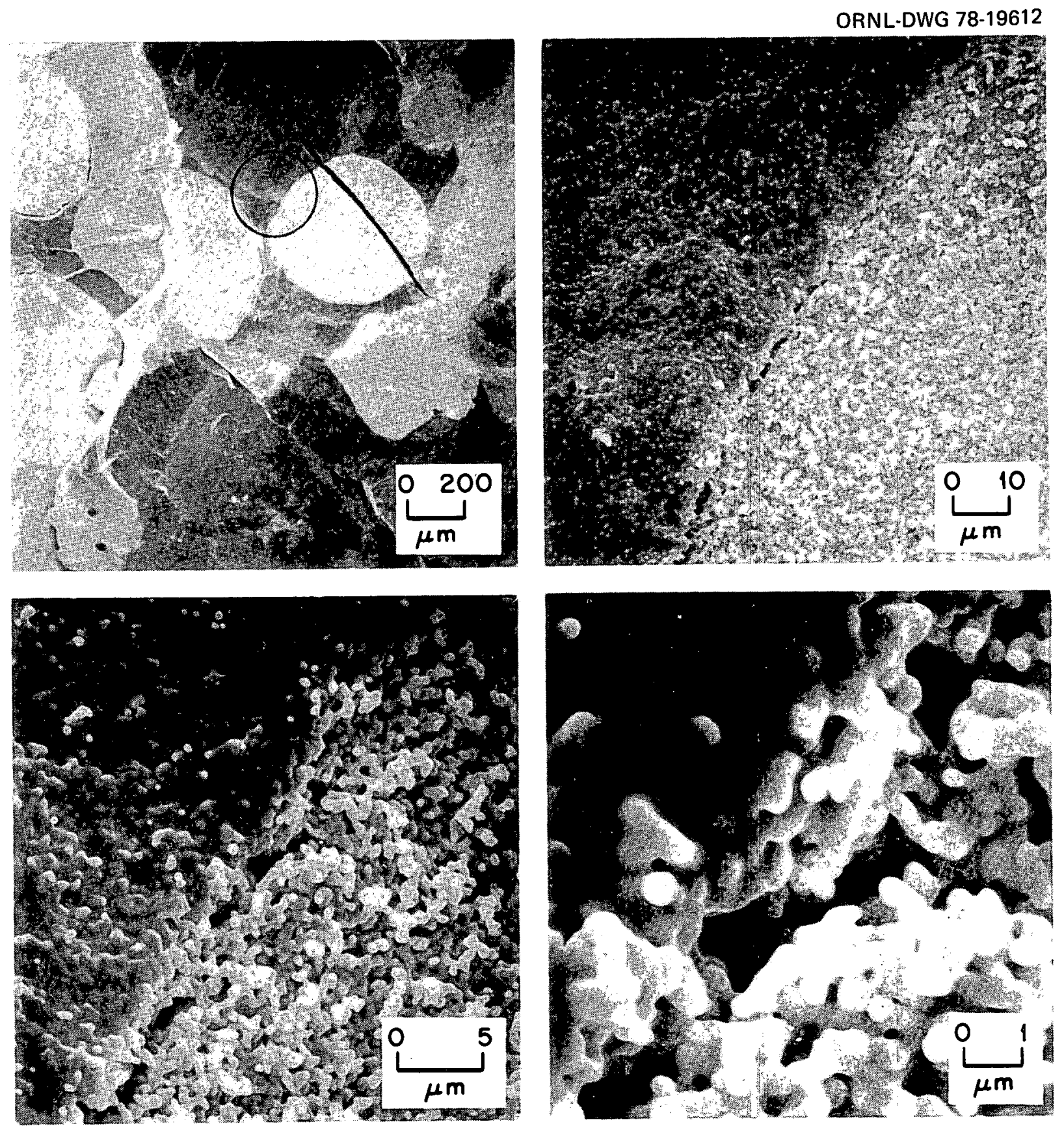

Fig. 14. Incomplete Sintering Between Microspheres Comprising a $\mathrm{UO}_{2}$ Pellet (Batch IGT-60, About $800-\mu \mathrm{m}$ Spheres, $1000^{\circ} \mathrm{C}$ Calcine). 
Many of the thoria and thoria-urania microsphere batches sintered poorly, even when the pellets were formed from uncalcined spheres. The thoria and thoria-urania microspheres, produced by either internal or external gelation (KFA method), sintered individually rather than between spheres (see Fig. 9). However, thoria-urania microspheres produced by the SNAM external gelation process sintered together better and are promising sphere-cal feed material.

\section{SPHERE-CAL BATCH SCREENING TESTS}

Twenty-one urania, one thoria, and five thoria-urania gel microsphere batches were tested for sphere-cal performance with a standard screening test, which was a modified ASTM sinterability test procedure (ASTM specification C-753-73, Sect. A2.2). The batches differed from each other in that various sphere forming and drying conditions were used during their production. A sample of microspheres from each of the urania batches was calcined at $600^{\circ} \mathrm{C}$ in $\mathrm{Ar}-4 \% \mathrm{H}_{2}$. The thoria and thoriaurania spheres were not calcined. The microspheres were then pressed with forming pressures between 138 and $414 \mathrm{MPa}(20,000$ and 60,000 psi). We used as high a pressure as possible, until end capping was observed, to obtain maximum green pellet densities. The pellets were then sintered at $1450^{\circ} \mathrm{C}$ in $\mathrm{Ar}-4 \% \mathrm{H}_{2}$ by using the standard schedule (see Fig. 12): $100^{\circ} \mathrm{C} / \mathrm{h}$ heating rate to $450^{\circ} \mathrm{C}$, then $300^{\circ} \mathrm{C} / \mathrm{h}$ heating rate to $1450^{\circ} \mathrm{C}$.

Green and calcined microsphere size, green and calcined sphere tap density, calcined sphere $0 / M$ ratio, green and sintered pellet geometric density, sintered pellet density (measured by mercury pycnometry), sphere weight loss during calcining, pellet weight loss during sintering, and pellet diametrical shrinkage were measured. Also, the gel microspheres themselves were characterized as to sinterability. Unpressed microspheres from each batch were measured for sintered sphere size, density, and weight loss during sintering. The heavy metal ratio ( $\mathrm{Th} / \mathrm{U}$ ) was determined for the mixed thoria-urania batches. Also polished cross sections of representative pellets from each gel microsphere batch were examined for porosity distribution, grain size, and internal cracking or other defects. These measurements for all of the gel microsphere batches that were tested are tabulated in the Appendix. 
We compared results of the sphere-cal pellet fabrication screening tests with the gel microsphere forming and drying conditions for each batch. Microstructures from the $\mathrm{UO}_{2}$ pellets could be categorized into one of three general groups: pellets with high density matrices (Fig. 15), pellets with porosity located mainly around remnant sphere boundaries (Fig. 16), and pellets with internal cracks (Fig. 17).

Our preliminary conclusions are discussed below. Pellets having dense matrices were often produced from batches of calcined spheres having $0 / \mathrm{M}$ ratios approaching 2.67, which corresponds to $\mathrm{U}_{3} \mathrm{O}_{8}$. However, most of these pellets crack apart during sintering as a result of water vapor release during reduction, phase changes, or excessive shrinkage. Pellets with a structure containing porosity around remnant sphere boundaries were often produced from microsphere batches dried slowly with room temperature air.

The aging changes in wet gel appear to cause sphere distortions and reduced dried gel densities. Aging also appears to contribute to gross cracking and other defects in pellets. Drying with room temperature air seems to contribute to pellet cracking, but this may be an effect of wet aging during the slow drying process. In addition, pellets pressed from spheres with diameters larger than $400 \mu \mathrm{m}$ usually contained more interna1 cracks.

Pellet inhomogeneity was a problem when several batches of gel microspheres were mixed, as shown in Fig. 18. Even within a batch grain size and porosity distribution sometimes varied between individual spheres comprising a pellet. This was more often the case for microspheres calcined at temperatures approaching $1000^{\circ} \mathrm{C}$.

Results to date suggest that the sphere-cal conditions that will produce the highest quality $\mathrm{UO}_{2}$ pellets are: minimum gel aging, fine microspheres $(50-400 \mu \mathrm{m})$, fast drying (warm air or oven), a calcination temperature of $600^{\circ} \mathrm{C}$, and a low $\mathrm{O} / \mathrm{M}$ ratio. The best urania pellets were produced from microspheres (batch GT-371) having minimum gel aging (about $5 \mathrm{~h}$ ), with a diameter of about $250 \mu \mathrm{m}$ when dried, dried at $220^{\circ} \mathrm{C}$ in an oven with a steam atmosphere, and calcined at $600^{\circ} \mathrm{C}$ in $\mathrm{Ar}-4 \% \mathrm{H}_{2}$. Excellent pellets with homogeneous microstructures and high densities ( $95.2 \%$ T.D.) were fabricated from these microspheres, as shown in Fig. 19. However, 

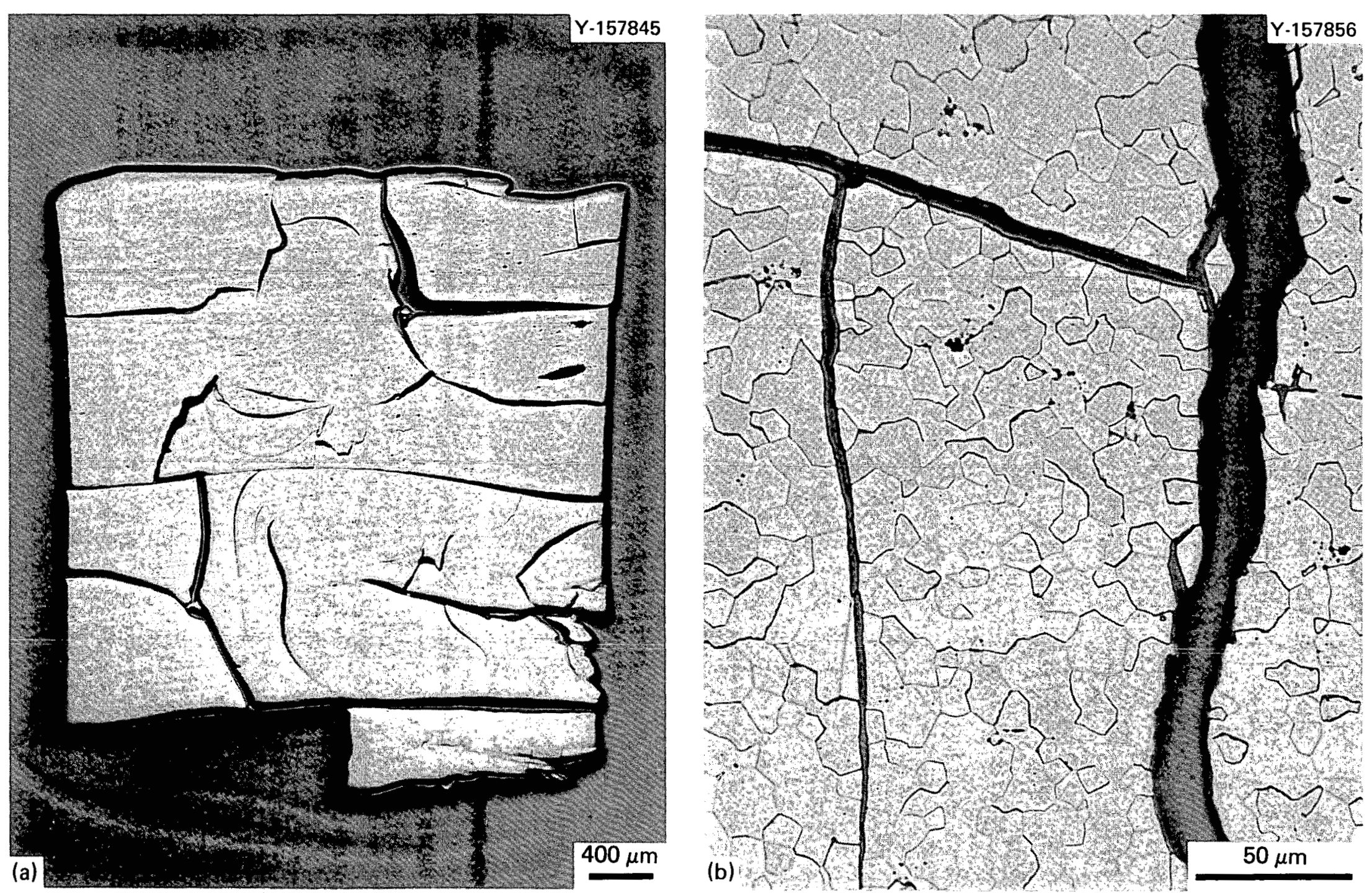

Fig. 15. Representative Microstructure of a UO 2 Pellet with High Density Matrix (Batch FGT-8, About $50-\mu \mathrm{m}$ Spheres, $450^{\circ} \mathrm{C}$ Calcine). (a) Polished section. (b) Etched $\left(\mathrm{H}_{2} \mathrm{SO}_{4}: 2 \mathrm{H}_{2} \mathrm{O}_{2}: 7 \mathrm{H}_{2} \mathrm{O}\right)$. 

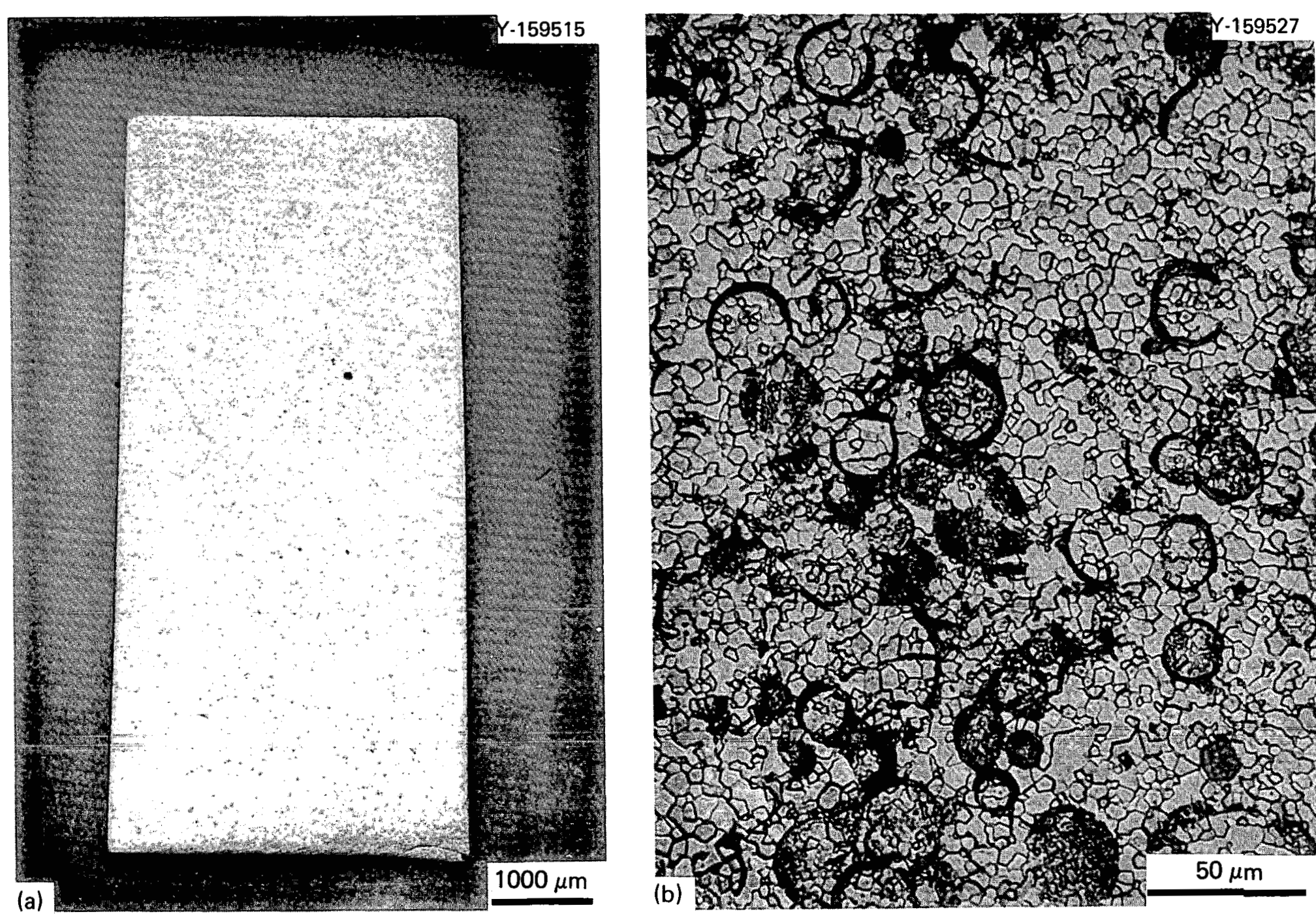

Fig. 16. Representative Microstructure of a UO 2 Pellet with Porosity Around Remnant Sphere Boundaries (Batch FGT-23A, About 50 $\mathrm{mm}$ Spheres, $600^{\circ} \mathrm{C}$ Calcine). (a) Polished Section. (b) Etched $\left(\mathrm{H}_{2} \mathrm{SO}_{4}: 2 \mathrm{H}_{2} \mathrm{O}_{2}: 7 \mathrm{H}_{2} \mathrm{O}\right)$. 

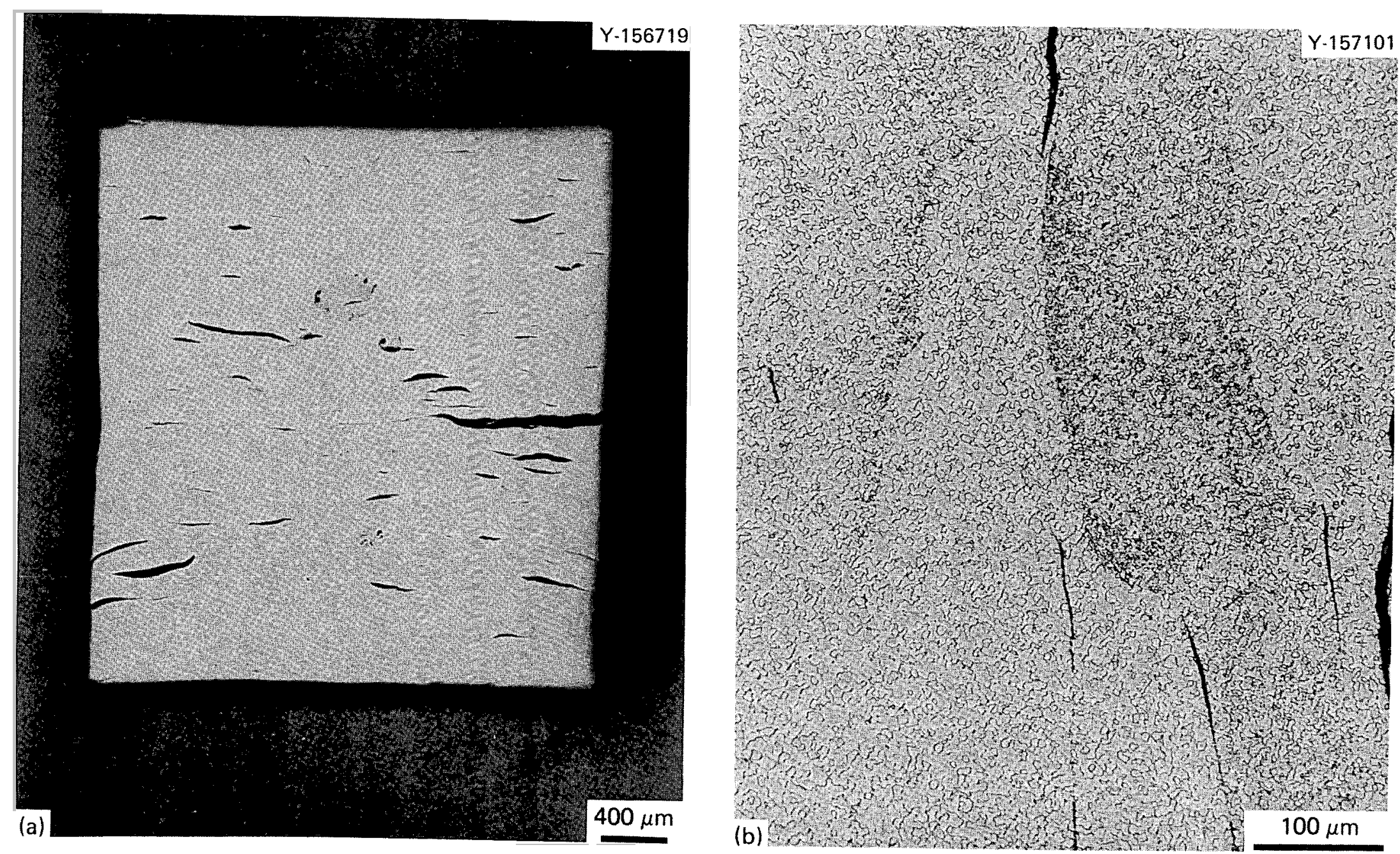

Fig. 17. Representative Microstructure of a UO 2 Pellet with Internal Cracks (Batch IGT-60, About 800- $\mu$ m Spheres, $600^{\circ} \mathrm{C}$ Calcine). (a) Polished section. (b) Etched $\left(\mathrm{H}_{2} \mathrm{SO}_{4}: 2 \mathrm{H}_{2} \mathrm{O}_{2}: 7 \mathrm{H}_{2} \mathrm{O}\right)$. 


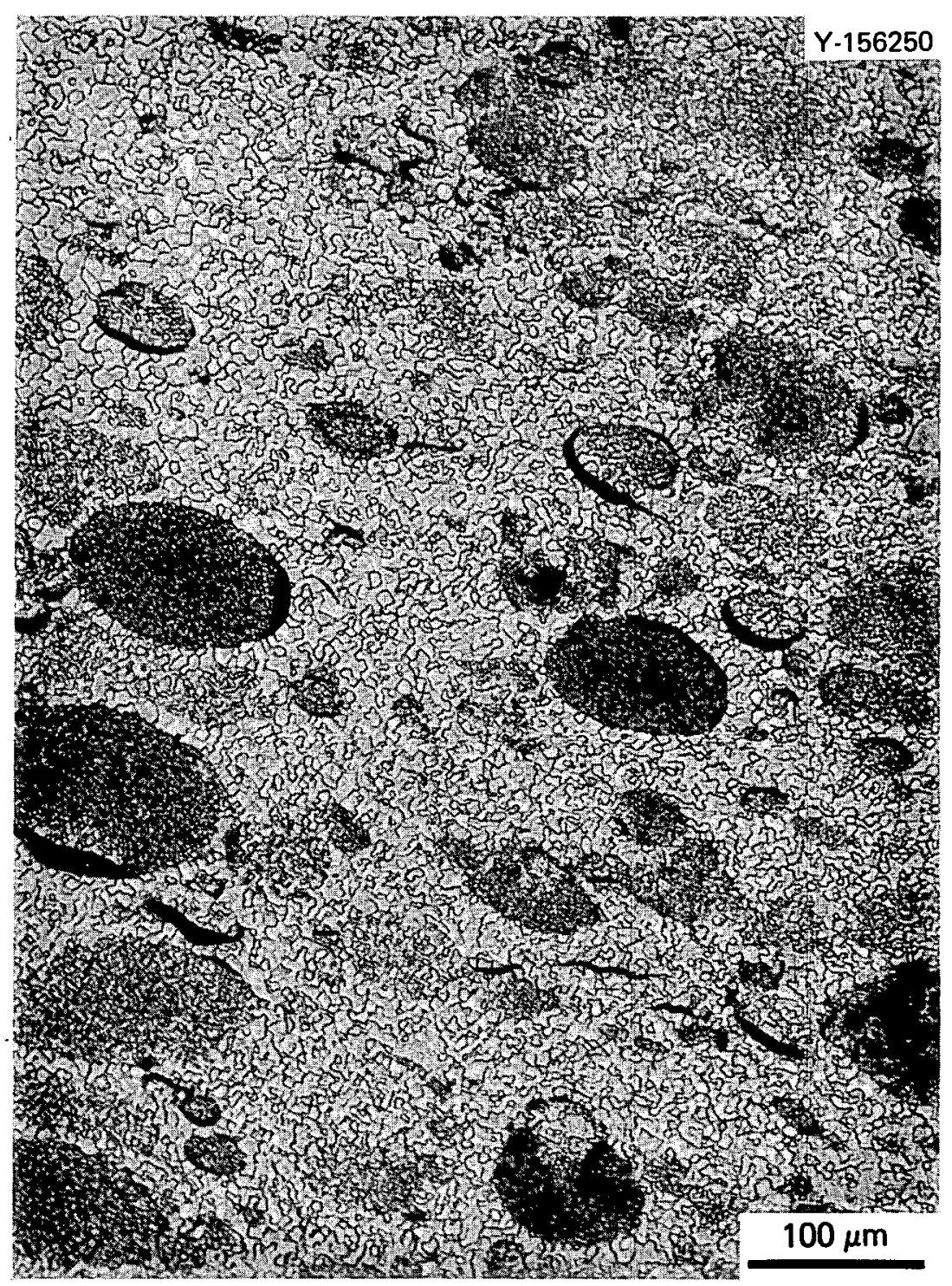

Fig. 18. Pellet Inhomogeneity (Mixed Batch, About 100- $\mu \mathrm{m}$ Spheres, $600^{\circ} \mathrm{C}$ Calcine). Etched $\left(\mathrm{H}_{2} \mathrm{SO}_{4}: 2 \mathrm{H}_{2} \mathrm{O}_{2}: 7 \mathrm{H}_{2} \mathrm{O}\right)$.

these microspheres oxidized during handling in air following calcination; and development work is necessary to determine a method to stabilize calcined microspheres. Our attempts to reproduce the excellent results from this microsphere batch have been only partially successful with other batches of gel microspheres. 

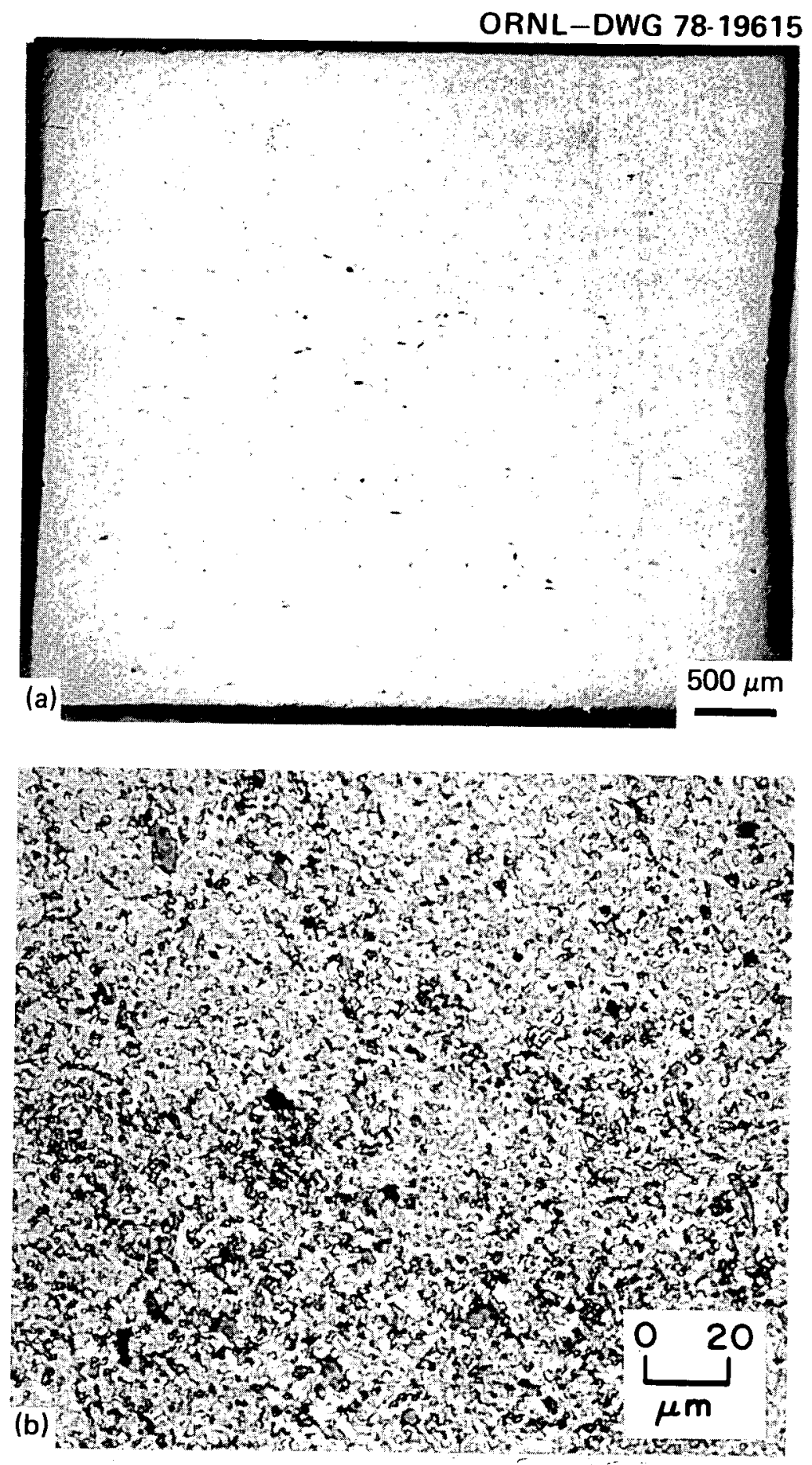

Fig. 19. $\mathrm{A} \mathrm{UO}_{2}$ Fuel Pellet Fabricated from Gel Microspheres (Batch GT-371, About 250- $\mathrm{mm}$ Spheres, $600^{\circ} \mathrm{C}$ Calcine). (a) Polished section. (b) Etched $\left(\mathrm{H}_{2} \mathrm{SO}_{4}: 2 \mathrm{H}_{2} \mathrm{O}_{2}: 7 \mathrm{H}_{2} \mathrm{O}\right)$. 
The best thoria-urania pellets were produced from microspheres (batch MGT-104) formed by the SNAM external gelation process, which have a soft gel structure. These microspheres, which contained about $20 \% \mathrm{U}$, had a diameter of about $700 \mu \mathrm{m}$ when dried and were dried at $200^{\circ} \mathrm{C}$ in an oven with a steam atmosphere. The SNAM-type microspheres compacted easily and sintered together to produce a fairly homogeneous structure (90.2\% T.D.), as shown in Fig. 20. Since these microspheres were not calcined before pressing, holes in the pellet structure were probably caused by the decomposition and release of the gel support polymer and other organics during sintering. Our development work is ongoing to optimize the calcination conditions of SNAM-type microspheres to be used as sphere-cal feed material.

\section{SUMMARY}

We studied each sphere-cal process step (microsphere gelation, drying, calcining, pellet pressing, and sintering) to try to determine the important parameters for the production of high quality $\mathrm{UO}_{2}, \mathrm{ThO}_{2}$, and $(\mathrm{Th}, \mathrm{U})_{2}$ fuel pellets. Urania microspheres used as pellet press feed material were formed by internal gelation, while thoria and mixed thoriaurania microspheres were produced by either internal or external gelation.

Excellent uranium oxide $\left(\mathrm{UO}_{2}\right)$ fuel pellets with homogeneous microstructures and densities (greater than 95\% T.D.) were produced from gelderived microspheres. Results to date suggest that the sphere-cal process conditions that will produce the highest quality $\mathrm{UO}_{2}$ pellets are: minimum gel aging, fine microspheres $(50-400 \mu \mathrm{m})$, fast drying (warm air or oven), a calcination temperature of $600^{\circ} \mathrm{C}$, and a low $\mathrm{O} / \mathrm{M}$ ratio. From a statistical experiment we determined that $\mathrm{UO}_{2}$ sintered pellet densities increase both with decreasing calcination temperature $\left(1000-600^{\circ} \mathrm{C}\right)$ and with decreasing forming pressure $(414-138 \mathrm{MPa})$. Thermogravimetric analyses revealed that a minimum calcination temperature of $600^{\circ} \mathrm{C}$ was necessary to ensure complete reduction of the $\mathrm{UO}_{3}$ microspheres to $\mathrm{UO}_{2}$. However, upon exposure to room air following calcination, the microspheres partially reoxidized. 


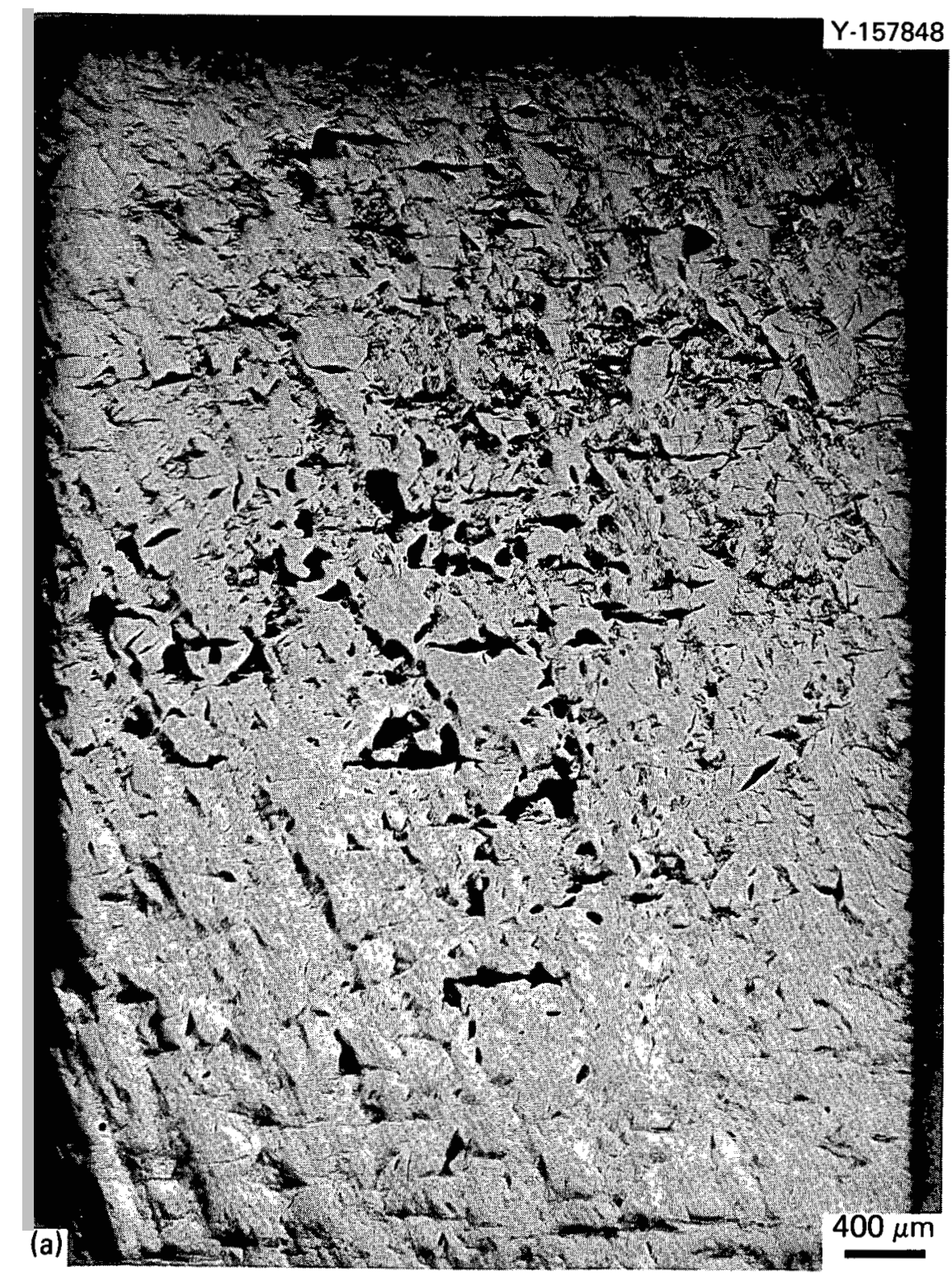

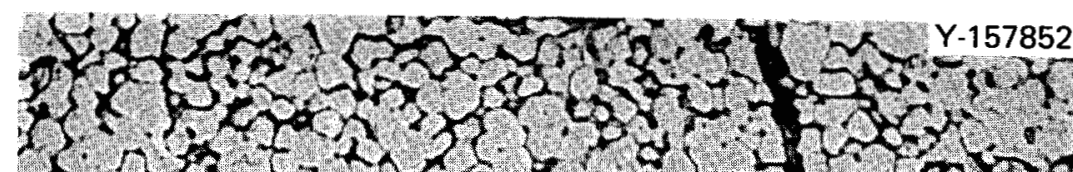

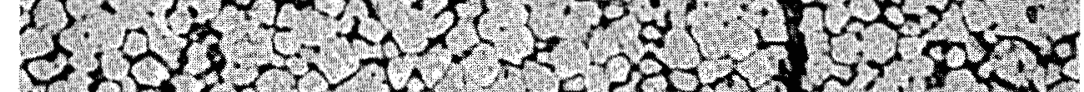

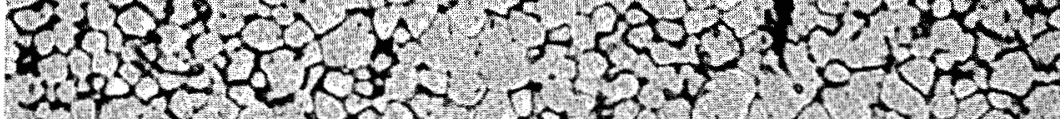

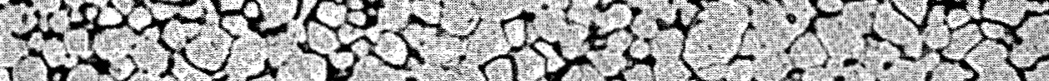

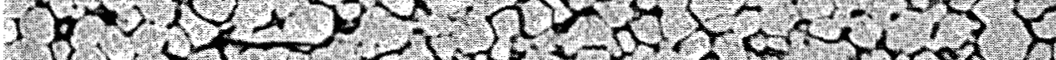

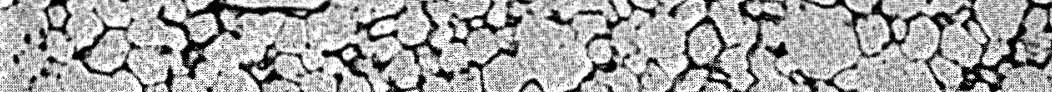

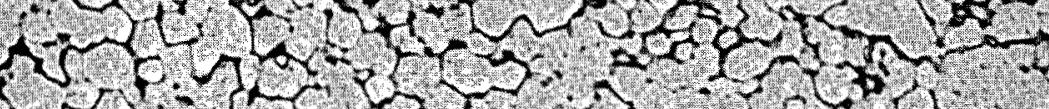

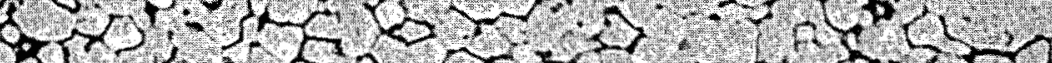

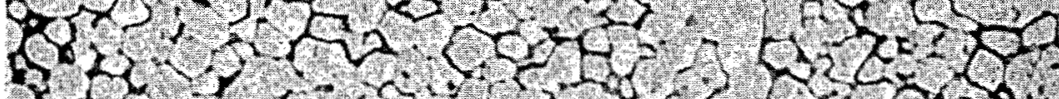

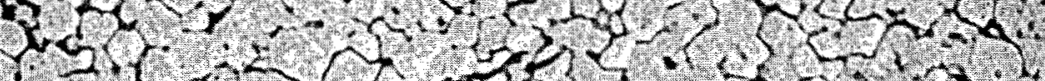

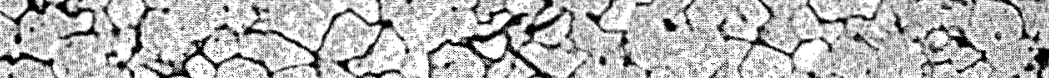

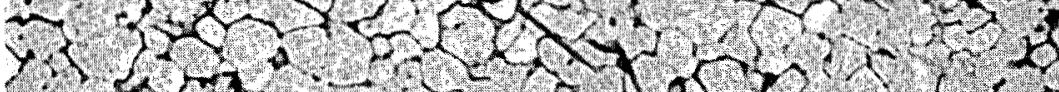

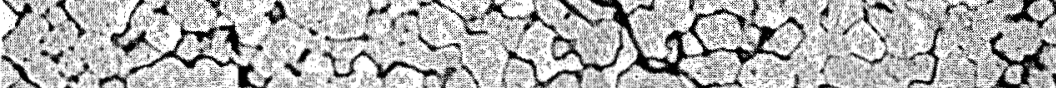

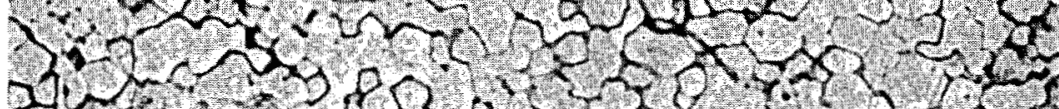

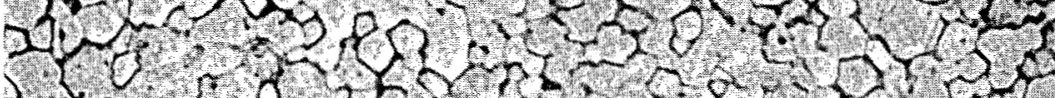

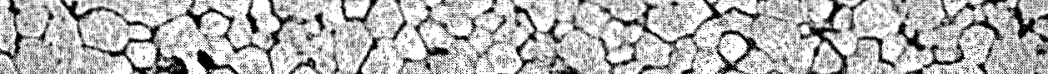

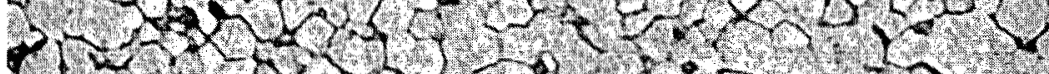

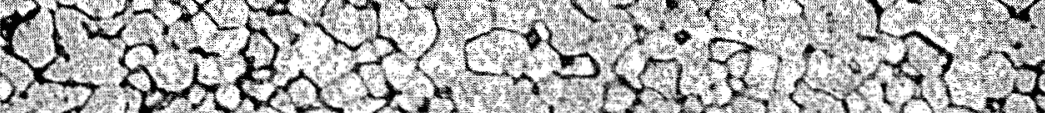

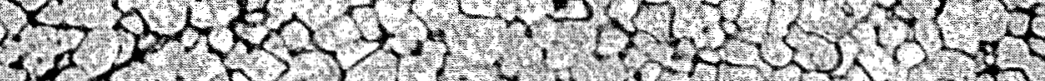

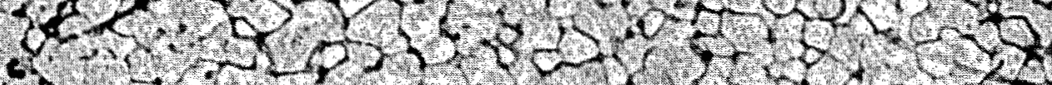

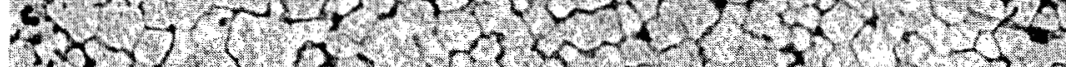

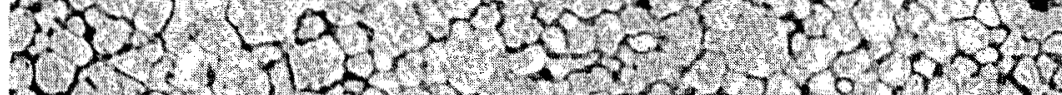

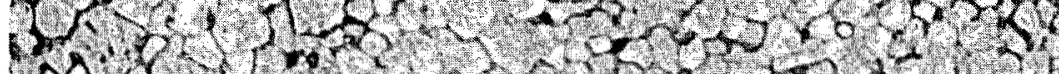

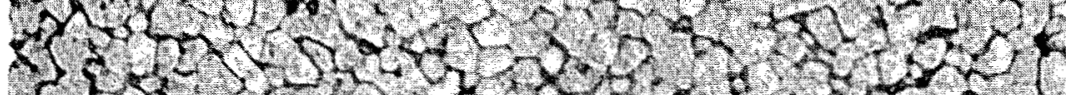

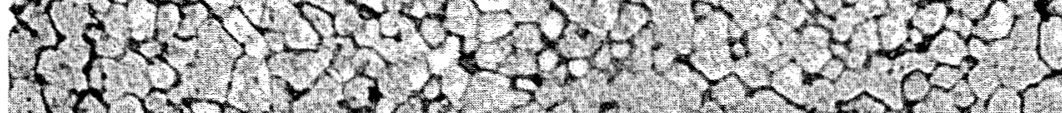
(b)

Fig. 20. A ( Th, U)O $)_{2}$ Pellet Fabricated from SNAM-Type Microspheres (Batch MGT-104, About 700- $\mu \mathrm{m}$ Spheres, External Gelation-SNAM Process, Th/U = 4). (a) As polished. (b) Etched $\left(30 \mathrm{H}_{3} \mathrm{PO}_{4}: 1 \mathrm{HF}\right)$. 
Thoria and mixed thoria-urania microspheres produced according to internal or external (KFA process) gelation flowsheets were hard and compacted poorly, even as dried. Pellet microstructures containing remnant microspheres and shards were obtained, and microspheres sintered individually rather than sintering between spheres. Urania microspheres produced by the "H" process gave similar results. However, thoria-urania microspheres produced by the SNAM external gelation process were softer, compacted easily, and sintered together to produce a more homogeneous pellet structure.

Our future development work will be directed toward optimization of sphere-cal process parameters. In particular, calcination schedules will be studied to stabilize the $\mathrm{O} / \mathrm{M}$ ratio of urania-bearing microspheres without appreciably decreasing their sinterability. Optimum microsphere size, gelation medium, and drying conditions must also be determined for urania sphere-cal feed material. Our development work will continue toward defining a (Th,U) $\mathrm{O}_{2}$ sphere-cal flowsheet with emphasis on gelation and calcination conditions.

\section{ACKNOWLEDGMENTS}

The authors would like to thank the following people for their invaluable help in preparing this report: M. S. Hendricks for laboratory work, W. J. Lackey and A. D. Ryan for work direction, N. H. Rouse for metallography, T. J. Henson for scanning electron microscopy, H. R. Livesay and M. A. Patrizio for preparing the figures, A. E. Pasto and R. R. Judkins for reviewing the manuscript, B. G. Ashdown for technical editing, and J. L. Bishop for preparing the manuscript for reproduction.

\section{REFERENCES}

1. W. J. Lackey and M. R. Schwab, "Dry Pressing of Sol-Gel ThO 2 ," pp. 2.17-2.18 in Ceramics Research and Development Operation Quart. Rep., Jan.-Mar. 1964, HW-81600, Hanford Atomic Products Operation, Richland, Washington. 
2. W. J. Lackey and R. A. Bradley, "Microstructure of So1-Gel-Derived (U, Pu)O $\mathrm{O}_{2}$ Microspheres and Pe1lets," Nucl. Technol. 14(6): 257-68 (1972); also ORNL/TM-3362 (June 1971).

3. H. H. Crain and C. R. Hutchison, Fabrication of Fuel Pellets from Sol-Gel Powders, WAPD-TM-581 (November 1966).

4. J M Robbins and J. G. Stradley, Fabrication of Sol-Gel Derived Thoria-Urania by Cold Pressing and Sintering, ORNL-4426 (July 1969).

5. R. A. Bradley and F. G. Kitts, "Fabrication of (U, Pu) $\mathrm{O}_{2}$ Pellets from Sol-Gel Microspheres," Bull. Am. Ceram. Soc. 50(9): 788 (1971).

6. Personal communication, Dr. G. Cogliati, Comitato Nazionale per L'energia Nucleare, Casaccia, Roma, Italy, to S. M. Tiegs, Oak Ridge National Laboratory, Ju1y 1978.

7. A. L. Lotts, comp., Fast Breeder Reactor Oxide Fuels Development Final Report, ORNL-4901 (November 1973).

8. W. J. Lackey and J. E. Selle, comps., Assessment of GeZ-Sphere-Pac Fuel for Fast Breeder Reactors, ORNL-5468 (October 1978).

9. R. L. Beatty, R. E. Norman, and K. J. Notz, comps., Gel-Sphere-Pac Fuel for Thermal Reactors - Assessment of Fabrication Technology and Irradiation Performance, ORNL-5469 (to be published).

10. J.B.W. Kanij, A. J. Noothout, and I. Votocik, "The KEMA U(VI) Process for the Production of U0 2 Microspheres," pp. 185-95 in Sol-Gel Process for Fuel Fabrication, IAEA-161, International Atomic Energy Agency, Vienna, 1974.

11. P. A. Haas, J. M. Begovich, A. D. Ryan, and J. S. Vavruska, Chemical Flowsheet Conditions for Intemal Gelation to Prepare Urania Spheres, ORNL/TM-6850 (in press).

12. G. Brambilla, P. Gerontopulos, D. Neri, and A. G. Facchini, "The SNAM Process for the Preparation of Ceramic Nuclear Fuel Microspheres," Energ. Nucl. (Mizan) 17: 217-33 (1970).

13. H. D. Ringel and E. Zimmer, "Simplified Preparation of $\mathrm{ThO}_{2}$ and (Th,U) $\mathrm{O}_{2}$ Fuel Kernels," Trans. Am. Nucl. Soc. 27: 292-93 (1977).

14. H. Landspersky and J. Bezucha, "Prepation of Sintered $\mathrm{UO}_{2}$ Pellets from Powdered $\mathrm{U}_{3} \mathrm{O}_{8}$ : Effect of Quality of Starting Material and of Binders Used for Compacting $\mathrm{U}_{3} \mathrm{O}_{8}$ on Reduction-Sintering Procedure," Jad. Energ. 16: 289-92 (1970). 
15. Personal Communication, D. P. Stinton, Oak Ridge National Laboratory, to S. M. Tiegs, Oak Ridge National Laboratory, April 1978. 


\section{APPENDIX}


$$
\text { . }
$$ 
Table Al. Urania Sphere-Cal Feed Material

\begin{tabular}{|c|c|c|c|c|c|c|c|c|c|c|c|c|c|c|c|c|}
\hline \multirow{2}{*}{ Batch } & \multirow{2}{*}{$\begin{array}{l}\text { Gelation } \\
\text { Flowsheet }\end{array}$} & \multirow{2}{*}{$\begin{array}{c}\text { Gelation } \\
\text { Equipment }\end{array}$} & \multirow{2}{*}{$\begin{array}{l}\text { Gelation } \\
\text { Organic }\end{array}$} & \multirow{2}{*}{$\begin{array}{l}\text { Gelation } \\
\text { Temperature } \\
\left.{ }^{\circ} \mathrm{C} C\right)\end{array}$} & \multirow{2}{*}{$\begin{array}{l}\text { Wet } \\
\text { Aging } d \\
\text { (h) }\end{array}$} & \multirow{2}{*}{$\begin{array}{l}\text { Drying } \\
\text { Conditions }^{e}\end{array}$} & \multirow{2}{*}{$\begin{array}{l}\text { Calcination } \\
\text { Temperature } \\
\left({ }^{\circ} \mathrm{C}\right)\end{array}$} & \multicolumn{3}{|c|}{ Sphere Size, um } & \multicolumn{2}{|c|}{$\underset{\mathrm{g} / \mathrm{cm}^{3}}{\text { Tap Density }}$} & \multirow{2}{*}{$\begin{array}{l}\text { o/U Rat1o } \\
\text { Calcined }\end{array}$} & \multicolumn{2}{|c|}{$\begin{array}{c}\text { Sphere weight } \\
\text { Loss, \% }\end{array}$} & \multirow{2}{*}{$\begin{array}{l}\text { Sphere Mercury } \\
\text { Density } \\
\text { (\% T.D.) }\end{array}$} \\
\hline & & & & & & & & Dried & Calcined & Sintered & $\overline{\text { Dried }}$ & Calcined & & $\begin{array}{c}\text { During } \\
\text { Calcining }\end{array}$ & $\begin{array}{c}\text { During } \\
\text { Sintering }\end{array}$ & \\
\hline CT-371 & Standard & Lab, F. & TCE & 65 & 5 & Steam $220^{\circ} \mathrm{C}$ & 400 & 250 & 271 & 85 & 0.79 & & 2.690 & 10.9 & 13.8 & 93.0 \\
\hline GT-371 & Standard & Lab, F. & TCE & 65 & s & Steam $220^{\circ} \mathrm{C}$ & 600 & 250 & 226 & 85 & 0.79 & 1.02 & 2.735 & 11.5 & 13.8 & 93.0 \\
\hline GI- 371 & Standard & Lab, F. & TCE & 65 & 5 & Steam $220^{\circ} \mathrm{C}$ & 800 & 250 & 222 & 85 & 0.79 & & 2.632 & 10.4 & 13.8 & 93.0 \\
\hline GT -412 & Standard & Lab, F. & TCE & 58 & 10 & Air R.T. & 600 & 68.5 & 60.5 & 37.5 & 1.32 & 2.28 & 2.426 & 18.8 & 18.8 & 100 \\
\hline GT- 357 & Standard & Lab, s.c. & TCE & 72 & 5 & Steam $220^{\circ} \mathrm{C}$ & 600 & 601 & 535 & 262 & 0.78 & 0.99 & 2.352 & $\begin{array}{l}17.2 \\
12.4\end{array}$ & 18.3 & 98.3 \\
\hline IGT-60 & Standard & Interim, s.c. & TCE & 70 & 140 & Steam $1220^{\circ} \mathrm{C}$ & 500 & 786 & & 397 & 0.65 & & 2.440 & 7.0 & 11.5 & 96.3 \\
\hline IGT-60 & Standard & Interim, s.c. & TCE & 70 & 140 & Steam $2220^{\circ} \mathrm{C}$ & 600 & 786 & 557 & 397 & 0.65 & 0.88 & 2.398 & $\begin{array}{l}9.6 \\
9.8\end{array}$ & 11.5 & 96.3 \\
\hline IGT -60 & Standard & Interim, s.c. & TCE & 70 & 140 & Steam $2220^{\circ} \mathrm{C}$ & 800 & 786 & & 397 & 0.65 & & 2.262 & 9.9 & 11.5 & 96.3 \\
\hline IGT-60 & Standard & Interim, s.c. & TCE & 70 & 140 & Steam $2220^{\circ} \mathrm{C}$ & 1000 & 786 & & 397 & 0.65 & & 2.203 & 10.0 & 11.5 & 96.3 \\
\hline $\begin{array}{l}\mathrm{J}-819 \\
\text { (Mixed) }\end{array}$ & Standard & Lab, F. & $\begin{array}{l}\text { TCE } \\
\text { (Most) }\end{array}$ & $\begin{array}{l}65 \\
\text { (Most) }\end{array}$ & & $\begin{array}{c}\text { Air R.T. } \\
\text { (Most) }\end{array}$ & 600 & & 280 & 39.6 & & 1.58 & 2.450 & & 6.9 & 98.5 \\
\hline IGT-68-69B & Standard & Interim, S.c. & TCE & 70 & 300 & Stean $200^{\circ} \mathrm{C}$ & 450 & & & & 0.76 & 0.99 & 2.59 & 10.5 & 12.5 & 96.6 \\
\hline GT- 469 & Standard & Lab, F. & TCE & 50 & 5 & Stean $220^{\circ} \mathrm{C}$ & 450 & 271 & & 105 & 0.88 & 1.28 & 2.56 & 15.4 & $\begin{array}{l}15.2 \\
15.4\end{array}$ & $\begin{array}{l}93.3 \\
97.9\end{array}$ \\
\hline IGT-61B & Standard & Interim, s.c. & TCE & 70 & 800 & Sceam $200^{\circ} \mathrm{C}$ & 450 & & & 323.5 & 0.75 & 0.99 & 2.63 & 7.7 & $\begin{array}{l}10.2 \\
10.1\end{array}$ & $\begin{array}{l}69.2 \\
96.9\end{array}$ \\
\hline $\begin{array}{c}J-829 \\
\text { (M1xed) }\end{array}$ & Standard & Lab, S.c. & $\begin{array}{l}\text { TCE } \\
\text { (Most) }\end{array}$ & $\begin{array}{l}70 \\
\text { (Most) }\end{array}$ & & $\begin{array}{l}\text { Steam } 220^{\circ} \mathrm{C} \\
\text { (Most) }\end{array}$ & 450 & 488 & 390 & & 0.81 & 1.09 & & 11.25 & & \\
\hline $\begin{array}{l}\mathrm{J}-829 \\
\text { (Mixed) }\end{array}$ & Standard & Lab, s.c. & $\begin{array}{l}\text { TCE } \\
\text { (Most) }\end{array}$ & $\begin{array}{l}70 \\
\text { (Most) }\end{array}$ & & $\begin{array}{l}\text { Steam } 220^{\circ} \mathrm{C} \\
\text { (Most) }\end{array}$ & 600 & 488 & 370 & & 0.81 & 1.11 & & 13.1 & & \\
\hline FGT-8 & Standard & Interim, $\mathrm{F}$. & 2EH & 53 & 20 & Steam $200^{\circ} \mathrm{C}$ & 450 & & 39 & & & 0.773 & & 9.5 & & \\
\hline FGT-8 & Standard & Interim, $\mathrm{F}$. & 2ЕH & 53 & $: 0$ & Steam $200^{\circ} \mathrm{C}$ & 600 & & & & & 1.04 & 2.46 & & & \\
\hline IGT-76 & Standard & Interim, s.c. & TCE & 53 & 10 & Stean $210^{\circ} \mathrm{C}$ & 600 & 567 & 486 & & 1.00 & 1.42 & & 9.2 & & \\
\hline FGT-1 & Standard & Interin, $\mathrm{F}$. & 2EH & 45 & 120 & $\begin{array}{l}\text { Air R.T. then } \\
\text { Oven } 200^{\circ} \mathrm{C}\end{array}$ & 600 & 82 & 113 & & 0.70 & 0.88 & 2.511 & $\begin{array}{r}9.4 \\
10.0\end{array}$ & 12.2 & 91.1 \\
\hline FGI-20A-I & Standard & Interim, $\mathrm{F}$. & 2हH & 50 & 10 & $\begin{array}{l}\text { Air } 80^{\circ} \mathrm{C} \text { then } \\
\text { Oven } 220^{\circ} \mathrm{C}\end{array}$ & 600 & 161 & 109 & & 1.52 & & 2.453 & 5.6 & & \\
\hline FGT-10 & Standard & Interim, F. & $2 \mathrm{EH}$ & 50 & 60 & $\begin{array}{l}\text { Air R.T. then } \\
\text { Oven } 200^{\circ} \mathrm{C}\end{array}$ & 600 & 212 & 137 & & 0.97 & 1.29 & 2.506 & 4.5 & & \\
\hline GT-468 & Standard & Lab, F. & TCE & 50 & 10 & Air R.T. & 600 & 215 & 180 & & 1.44 & 2.03 & 2.328 & 16.8 & & \\
\hline IGT-61A & Standard & Interim, s.c. & TCE & 70 & 800 & Air R.T. & 600 & 626 & 502 & & 1.06 & 1.47 & 2.270 & 16.1 & & \\
\hline FGT-23B & Standard & Interim, F. & $2 \mathrm{EH}$ & so & 40 & $\begin{array}{l}\text { Air R.T. then } \\
\text { Oven } 225^{\circ} \mathrm{C}\end{array}$ & 600 & 36 & 33 & & 1.46 & 1.98 & 2.457 & 7.1 & & \\
\hline FGT-23A & Standard & Interim, $\mathrm{F}$. & 2ЕH & 50 & 40 & $\begin{array}{l}\text { Air R.T. then } \\
\text { Oven } 225^{\circ} \mathrm{C}\end{array}$ & 600 & 32 & 34 & & 1.52 & 2.19 & 2.274 & 7.6 & & \\
\hline но6 & $\begin{array}{l}\text { "H" } \\
\text { Process }\end{array}$ & Lab & $2 \mathrm{EH}$ & 88 & 5 & $\begin{array}{l}\text { Air } 60^{\circ} \mathrm{C} \text { then } \\
\text { oven } 225^{\circ} \mathrm{C}\end{array}$ & 600 & 181 & 151 & & 2.17 & 3.67 & 2.28 & 9.1. & & \\
\hline FGT-21 & Standard & Interim, F. & 2EH & so & 60 & $\begin{array}{l}\text { Air R.T. then } \\
\text { Oven } 225^{\circ} \mathrm{C}\end{array}$ & 600 & 38 & 26 & & 1.02 & 1.62 & 2.372 & 7.4 & & \\
\hline FGT-20 & Standard & Interim, $\mathrm{F}$, & 2EH & so & 80 & $\begin{array}{l}\text { Air R.T, then } \\
\text { Oven } 225^{\circ} \mathrm{C}\end{array}$ & 600 & 155 & 274 & & 1.23 & 1.65 & 2.34 & 7.3 & & \\
\hline
\end{tabular}

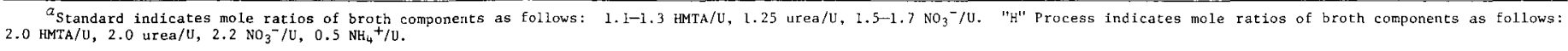

b. is abbreviation for fines; S.C. is abbreviation for small coarse. Lab indicates small scale with batch preparation of broth and typically 0.1 to $0.6 \mathrm{~kg}$ product per test. Interim
indicates engineering scale with continuous preparation of broth and more than $0.6 \mathrm{~kg}$ product per test.

$c_{\text {TCE }}$ is abbreviation for trichloroethylene; 2 EH is abbreviation for 2-ethyl-1-hexanol.

$\hat{a}_{\text {Wet }}$ aging indicates elapsed time between gelation and final drying as $5,10,20,40,60$, etc. h.

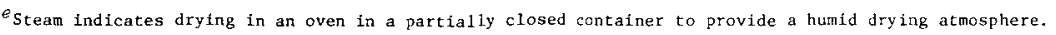


Table A2. $\mathrm{UO}_{2}$ Sphere-Cal Pellets

\begin{tabular}{|c|c|c|c|c|c|c|c|c|c|c|}
\hline Batch & Pellet & $\begin{array}{l}\text { Calcination } \\
\text { Temperature } \\
\quad\left({ }^{\circ} \mathrm{C}\right)\end{array}$ & $\begin{array}{l}\text { Forming } \\
\text { Pressure } \\
\quad \text { (MPa) }\end{array}$ & $\begin{array}{l}\text { Green Bulk } \\
\text { Density } \\
\text { (\% T.D.) }\end{array}$ & $\begin{array}{l}\text { Sintered } \\
\text { Bulk Density } \\
\text { (\% T.D.) }\end{array}$ & $\begin{array}{l}\text { Mercury } \\
\text { Density } \\
(\% \text { T.D.) }\end{array}$ & $\begin{array}{l}\text { Weight } \\
\text { Loss } \\
(\%)\end{array}$ & $\begin{array}{c}\text { Diametrical } \\
\text { Shrinkage } \\
(\%)\end{array}$ & $\begin{array}{l}\text { Pellet } \\
\text { Integrity }\end{array}$ & Microstructure \\
\hline GT-371 & SP-1-1 & 400 & 138 & 31.8 & & & 3.4 & 26.5 & Cracked & \\
\hline GT-371 & $S P-1-2$ & 400 & 138 & 31.7 & 78.3 & & 6.4 & 24.5 & Cracked & Homogeneous. \\
\hline GT-371 & $S P-7-4$ & 400 & 207 & 38.0 & & & 10.2 & 23.3 & Cracked & \\
\hline$G T-371$ & SP-2-9 & 400 & 276 & 39.5 & & & 7.8 & 22.4 & Cracked & \\
\hline GT-371 & SP-3-1 & 600 & 138 & 36.1 & 87.9 & 93.4 & 3.8 & 23.9 & Good & Excellent homogeneity. \\
\hline GT-371 & $S P-4-4$ & 600 & 207 & 34.0 & 89.6 & 95.2 & 2.8 & 22.5 & Good & Excellent homogeneity. \\
\hline GT-371 & SP-5-7 & 600 & 276 & 42.9 & 87.2 & & 3.1 & 19.8 & Cracked & \\
\hline GT-371 & $S P-6-9$ & 600 & 276 & 44.2 & & & 3.8 & 19.4 & Cracked & \\
\hline GT-371 & $S P-10-1$ & 800 & 138 & 38.8 & 86.9 & 90.5 & 3.8 & 22.3 & Good & \\
\hline GT-371 & SP-11-4 & 800 & 207 & 42.1 & 87.5 & & 3.4 & 20.7 & Cracked & \\
\hline GT-371 & $S P-12-7$ & 800 & 276 & 44.1 & 88.6 & 90.6 & 3.4 & 19.5 & Good & Very homogeneous, stress crack. \\
\hline GT-412 & SP-13-1 & 600 & 138 & 41.1 & 92.2 & 93.1 & 1.9 & 23.6 & Good & \\
\hline GT-412 & $\mathrm{SP}-14-4$ & 600 & 207 & 45.7 & 96.5 & 96.3 & 1.9 & 21.8 & Good & Some porosity around remnant spheres. \\
\hline$G T-412$ & $\mathrm{SP}-15-7$ & 600 & 276 & 49.1 & 95.1 & 97.4 & 2.2 & 20.2 & Good & \\
\hline GT-357 & SP-16-1 & 600 & 138 & 44.7 & 95.1 & 98.4 & 2.7 & 25.1 & Good & Internal cracks, few bad spheres. \\
\hline GT-357 & $\mathrm{SP}-16-4^{b}$ & 600 & 207 & 47.2 & 94.5 & 98.9 & 2.4 & 20.3 & Good & Internal cracks, few bad spheres. \\
\hline GT -357 & $S P-16-7^{b}$ & 600 & 276 & 49.8 & 93.3 & 99.1 & 2.8 & 18.9 & Good & Internal cracks, few bad spheres. \\
\hline IGT-60 & $S P-17-1$ & 600 & 138 & 44.6 & 93.7 & & 2.3 & 21.4 & Cracked & \\
\hline IGT-60 & $S P-17-4$ & 600 & 207 & 47.2 & 94.2 & 97.5 & 2.2 & 19.9 & Good & Internal cracks, few bad spheres. \\
\hline IGT-60 & $S P-17-7$ & 600 & 276 & 50.7 & 94.5 & 96.2 & 2.7 & 18.5 & Good & Internal cracks, few bad spheres. \\
\hline IGT -60 & $S P-19-1 A$ & 600 & 138 & 42.9 & 84.6 & & 4.8 & 20.9 & Cracked & Internal cracks. \\
\hline IGT -60 & $S P-19-4$ & 600 & 207 & 45.5 & 85.9 & & 4.0 & 19.4 & Good & \\
\hline $\operatorname{IGT}-60$ & $S P-19-7$ & 600 & 276 & 47.5 & 80.4 & & 7.5 & 17.7 & Cracked & Internal cracks. \\
\hline$J-819$ & SP-19-1B & 600 & 138 & 43.0 & 86.9 & 97.3 & 2.7 & 21.4 & Good & \\
\hline$J-819$ & $S P-19-2$ & 600 & 207 & 46.0 & & & 3.0 & & Broke & $\begin{array}{l}\text { Sphere-to-sphere varfability, some } \\
\text { porosity around remnant spheres. }\end{array}$ \\
\hline $\mathrm{J}-819$ & SP-19-3 & 600 & 276 & 49.1 & 88.9 & 99.7 & 3.1 & 18.7 & Good & \\
\hline IGT-68-69B & $\mathrm{SP}-25-1$ & 450 & 172 & 41.4 & 92.2 & & 2.0 & 22.9 & $\begin{array}{l}\text { Slight } 1 \text { y } \\
\text { cracked }\end{array}$ & Few cracks and bad spheres. \\
\hline GT-469 & $\mathrm{SP}-25-2$ & 450 & 172 & 40.9 & 91.3 & & 4.0 & 23.7 & $\begin{array}{l}\text { Slightly } \\
\text { cracked }\end{array}$ & $\begin{array}{l}\text { Some porosity around remnant spheres, } \\
\text { few bad spheres. }\end{array}$ \\
\hline IGT-61B & $\mathrm{SP}-27-1$ & 450 & 172 & 42.1 & 88.0 & & 5.5 & 21.9 & Good & Few cracks and bad spheres. \\
\hline IGT-61 B & $\mathrm{SP}-27-2$ & 450 & 172 & 42.9 & 92.0 & & 3.9 & 22.3 & Good & $\begin{array}{l}\text { Sorse varability between spheres, } \\
\text { small amount of porosity around } \\
\text { remnant spheres. }\end{array}$ \\
\hline$J-829$ & $\mathrm{SP}-32-1$ & 450 & 207 & 46.6 & 93.4 & & 4.7 & 21.0 & Cracked & \\
\hline$J-829$ & $\mathrm{SP}-31-2$ & 600 & 207 & 47.9 & 94.8 & & 4.6 & 20.7 & Cracked & \\
\hline FGT-8 & $\mathrm{SP}-34-1$ & 450 & 207 & 39.8 & & & 8.1 & & Broke & Very dense, homogeneous matrix. \\
\hline FGT-8 & $\mathrm{SP}-34-2$ & 450 & 207 & 38.7 & & & 8.1 & & Broke & Very dense, homogeneous matrix. \\
\hline FGT-8 & $\mathrm{SP}-38-1^{c}$ & 450 & 138 & 34.9 & & & 9.0 & 21.2 & Broke & Poor, internal cracks, volds. \\
\hline FGT-8 & $5 P-38-2^{C}$ & 450 & 207 & 34.4 & & & 10.9 & 22.4 & Broke & Poor, internal cracks, voids. \\
\hline FGT-8 & $\mathrm{SP}-38-3^{\mathrm{C}}$ & 450 & 276 & 39.5 & & & 8.3 & 21.1 & Broke & Poor, internal cracks, voids. \\
\hline FGT-8 & $S P-39-1^{C}$ & 450 & 138 & 35.6 & & & 8.8 & 25.2 & Broke & Poor, Internal cracks, voids. \\
\hline FGT -3 & $\mathrm{SP}-39-2^{d}$ & 450 & 207 & 40.2 & & & 10.9 & 23.3 & Broke & Few internal voids. \\
\hline IGT-76 & $S P-34-3$ & 600 & 207 & 45.4 & & & 3.4 & & Broke & Few Internal voids, dense matrix. \\
\hline
\end{tabular}


Table A2. (Continued)

\begin{tabular}{|c|c|c|c|c|c|c|c|c|c|c|}
\hline Batch & Pellet & $\begin{array}{l}\text { Calcination } \\
\text { Temperature } \\
\left({ }^{\circ} \mathrm{C}\right)\end{array}$ & $\begin{array}{l}\text { Forming } \\
\text { Pressure } \\
\quad(\mathrm{MPa})\end{array}$ & $\begin{array}{l}\text { Green Bulk } \\
\text { Dens } 1 \text { tya } \\
(\% \text { T.D. })\end{array}$ & $\begin{array}{l}\text { Sintered } \\
\text { Bulk Densicy } \\
\text { (\% T.D.) }\end{array}$ & $\begin{array}{l}\text { Mercury } \\
\text { Density } \\
\text { (\% T.D.) }\end{array}$ & $\begin{array}{l}\text { Weight } \\
\text { Loss } \\
(\%)\end{array}$ & $\begin{array}{l}\text { Diametrical } \\
\text { Shrinkage } \\
\qquad \%)\end{array}$ & $\begin{array}{l}\text { Pe1let } \\
\text { Integrity }\end{array}$ & Microstructure \\
\hline FGT-1 & $\mathrm{SP}-31-3$ & 600 & 207 & 45.8 & & & 3.7 & & Broke & $\begin{array}{l}\text { Very dense matrix, few remant } \\
\text { spheres. }\end{array}$ \\
\hline $\mathrm{FGT}-1$ & $\mathrm{SP}-37-1^{c}$ & 600 & 138 & 41.0 & 82.4 & 94.5 & 5.4 & 20.6 & Good & $\begin{array}{l}\text { Some internal cracks, voids, and } \\
\text { porosity around remnant spheres. }\end{array}$ \\
\hline FGT-1 & $\mathrm{SP}-37-2^{\circ}$ & 600 & 207 & 45.9 & 86.1 & 96.2 & 4.4 & 18.3 & Good & $\begin{array}{l}\text { Some internal cracks and voids near } \\
\text { edge. }\end{array}$ \\
\hline FGI-1 & $5 P-37-3^{c}$ & 600 & 276 & 48.9 & 89.3 & & 5.1 & 18.2 & Good & Internal cracks, edge discoloration. \\
\hline FGT-20AI & $S P-42-1$ & 600 & 345 & 49.9 & 95.2 & & 2.6 & 20.4 & Cracked & $\begin{array}{l}\text { End capping, some porosity around } \\
\text { remnant spheres. }\end{array}$ \\
\hline FGT-20AI & $S P-42-2$ & 600 & 276 & 46.4 & 92.0 & & 3.1 & 21.1 & cood & Some porosity around remnant spheres. \\
\hline FGT -10 & $S P-44-1$ & 600 & 207 & 46.6 & 86.6 & & 4.6 & 19.9 & Cracked & Internal cracks. \\
\hline FGT -10 & $S P-44-2$ & 600 & 276 & 49.7 & 86.9 & & 5.2 & 18.8 & Cracked & Internal cracks. \\
\hline FGT -10 & SP-44-3 & 600 & 345 & 50.7 & 86.4 & & 6.2 & 17.9 & Cracked & Internal cracks. \\
\hline GT -468 & $S P-45-1$ & 600 & 207 & 46.4 & 88.0 & & 2.8 & 19.9 & Cracked & Internal cracks and voids. \\
\hline$G T-468$ & $S P-45-2$ & 600 & 276 & 49.3 & 90.6 & & 2.7 & 19.4 & Cracked & Internal cracks and voids. \\
\hline GT-468 & $\mathrm{SP}-45-3$ & 600 & 345 & 51.2 & 81.1 & & 12.8 & 18.4 & Cracked & Internal cracks and voids. \\
\hline IGT-61A & $S P-46-1$ & 600 & 207 & 40.4 & 88.7 & & 2.6 & 22.5 & Good & Few interna1 cracks. \\
\hline IGT-61A & $\mathrm{SP}-46-2$ & 600 & 276 & 46.4 & 88.9 & & 2.0 & 18.9 & Flaked & Few internal cracks. \\
\hline $\mathrm{FGT}-23 \mathrm{~B}$ & $\mathrm{SP}-47-1$ & 600 & 207 & 41.0 & & & 3.1 & & Broke & $\begin{array}{l}\text { Some porosity around remnant spheres, } \\
\text { end capping, pressing lamination. }\end{array}$ \\
\hline FGT-23B & $S P \sim 47-2$ & 600 & 276 & 43.9 & & & 3.4 & & Broke & Some porosity around remnant spheres. \\
\hline FGT-23A & $\mathrm{SP}-48-1$ & 600 & 207 & 42.9 & 86.0 & & 2.1 & 20.6 & Broke & Some porosity around remnant spheres. \\
\hline FGT-23A & $5 P-48-2$ & 600 & 276 & 44.4 & 87.2 & & 2.1 & 20.2 & Broke & Some porosity around remnant spheres. \\
\hline ноб & $\mathrm{sP}-49-2$ & 600 & 207 & 49.7 & 76.3 & & 2.8 & 14.5 & Crumbly & $\begin{array}{l}\text { Internal cracks, remnant sphere } \\
\text { structure with little sintering } \\
\text { between spheres. }\end{array}$ \\
\hline но6 & $\mathrm{SP}-49-3$ & 600 & 276 & 51.2 & 78.7 & & 3.4 & 14.7 & Crumbly & $\begin{array}{l}\text { Internal cracks, remnant sphere } \\
\text { structure with little sintering } \\
\text { between spheres. }\end{array}$ \\
\hline FGT-21 & $\mathrm{SP}-50-1$ & 600 & 207 & 39.7 & & & 2.8 & 23.3 & Broke & $\begin{array}{l}\text { Some porosity around remnant spheres, } \\
\text { pressing lamination. }\end{array}$ \\
\hline FGT-21 & SP-50-2 & 600 & 276 & 39.6 & 85.2 & & 3.0 & 22.3 & Good & $\begin{array}{l}\text { Pew large cracks, some porosity } \\
\text { around remnant spheres. }\end{array}$ \\
\hline FGT-20 & $\mathrm{SP}-51-1$ & 600 & 138 & 36.8 & 82.8 & & 3.1 & 23.7 & Good & Porosity around remnant spheres. \\
\hline FGT-20 & $S P-51-2$ & 600 & 207 & 39.6 & 87.3 & & 2.6 & 23.4 & Good & \\
\hline
\end{tabular}

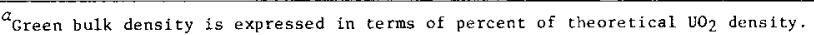

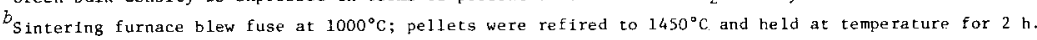

${ }^{c}$ Sterotex was added to the pellet press feed.

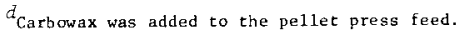


Table A3. Thoria and Thoria-Urania Sphere-Cal Feed Materiala

\begin{tabular}{|c|c|c|c|c|c|c|c|c|c|}
\hline \multirow{2}{*}{ Batch } & \multirow{2}{*}{$\begin{array}{l}\text { Gelation } \\
\text { Flowsheet }\end{array}$} & \multirow{2}{*}{$\begin{array}{l}\text { Th/U } \\
\text { Ratio }\end{array}$} & \multirow{2}{*}{$\begin{array}{l}\text { Gelation } \\
\text { Conditions }\end{array}$} & \multirow{2}{*}{$\begin{array}{l}\text { Drying } \\
\text { Conditions } b\end{array}$} & \multicolumn{2}{|c|}{$\underset{\mu \mathrm{m}}{\text { Sphere Size, }}$} & \multirow{2}{*}{$\begin{array}{l}\text { Tap } \\
\text { Density } \\
\text { Dried } \\
\left(\mathrm{g} / \mathrm{cm}^{3}\right)\end{array}$} & \multirow{2}{*}{$\begin{array}{c}\text { Sphere Weight } \\
\text { Loss During } \\
\text { Sintering } \\
(\%)\end{array}$} & \multirow{2}{*}{$\begin{array}{l}\text { Sphere } \\
\text { Mercury } \\
\text { Density } \\
\text { (\% T.D.) }\end{array}$} \\
\hline & & & & & Dried & Sintered & & & \\
\hline MGT-103 & $\begin{array}{l}\text { Internal } \\
\text { gelation }\end{array}$ & 3.60 & $\begin{array}{l}\text { Perc mineral } \\
\text { oil, } 95^{\circ} \mathrm{C}\end{array}$ & Steam $-220^{\circ} \mathrm{C}$ & 2463 & & 1.72 & 16.9 & 89.5 \\
\hline MGT-104 & $\begin{array}{l}\text { External, } \\
\text { SNAM }\end{array}$ & 3.97 & $\begin{array}{l}\mathrm{NH}_{3} \text { gas, then } \\
\mathrm{NH}_{4} \mathrm{OH}\end{array}$ & Steam- $200^{\circ} \mathrm{C}$ & 724 & 573 & 2.23 & & \\
\hline Th-U-3.84 & $\begin{array}{l}\text { External, } \\
\text { KFA-Jülich }\end{array}$ & 7.27 & $\begin{array}{l}\mathrm{NH}_{3} \text { gas, then } \\
\mathrm{NH}_{4} \mathrm{OH}+\mathrm{NH}_{4} \mathrm{NO}_{3}\end{array}$ & Steam $-220^{\circ} \mathrm{C}$ & & & 2.20 & 3.4 & 100 \\
\hline MGT-111 & $\begin{array}{l}\text { External, } \\
\text { KFA-Jïlich }\end{array}$ & $100 \% \mathrm{ThO}_{2}$ & $\begin{array}{l}\mathrm{NH}_{3} \text { gas, then } \\
\mathrm{NH}_{4} \mathrm{OH}+\mathrm{NH}_{4} \mathrm{NO}_{3}\end{array}$ & Steam-224 $4^{\circ} \mathrm{C}$ & & & 2.65 & 3.3 & 100 \\
\hline MGT-127 & $\begin{array}{l}\text { External, } \\
\text { KFA-Jülich }\end{array}$ & 5.93 & $\begin{array}{l}\mathrm{NH}_{3} \text { gas, then } \\
\mathrm{NH}_{4} \mathrm{OH}+\mathrm{NH}_{4} \mathrm{NO}_{3}\end{array}$ & Steam $-220^{\circ} \mathrm{C}$ & & & 2.11 & 4.0 & 100 \\
\hline GT-484 & $\begin{array}{l}\text { Internal } \\
\text { gelation }\end{array}$ & 2.86 & TCE, ${ }^{\mathrm{C}} 69^{\circ} \mathrm{C}$ & Steam $-250^{\circ} \mathrm{C}$ & & & 2.09 & & \\
\hline
\end{tabular}

Note: The thoria and mixed thoria-urania batches were not calcined before pressing.

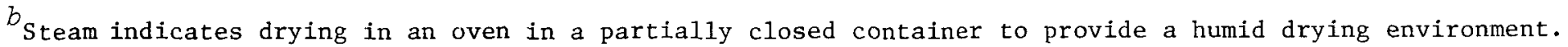

$c_{\text {Perc }}$ is abbreviation for perchloroethylene, TCE is abbreviation for trichloroethylene. 


\section{Table A4. Thoria and Thoria-Urania Sphere-Cal Pelletsa}

\begin{tabular}{|c|c|c|c|c|c|c|c|c|c|c|c|}
\hline \multirow{2}{*}{ Batch } & \multirow{2}{*}{ Pellet } & \multicolumn{2}{|c|}{ Composition } & \multirow{2}{*}{$\begin{array}{l}\text { Forming } \\
\text { Pressure } \\
\text { (MPa) }\end{array}$} & \multirow{2}{*}{$\begin{array}{c}\text { Green Bulk } \\
\text { Density } \\
(\% \text { T.D.) }\end{array}$} & \multirow{2}{*}{$\begin{array}{l}\text { Sintered } \\
\text { Bulk Density } \\
\text { (\% T.D.) }\end{array}$} & \multirow{2}{*}{$\begin{array}{l}\text { Mercury } \\
\text { Density } \\
\text { (\% T.D.) }\end{array}$} & \multirow{2}{*}{$\begin{array}{l}\text { Weight } \\
\text { Loss } \\
(\%)\end{array}$} & \multirow{2}{*}{$\begin{array}{c}\text { Diametrical } \\
\text { Shrinkage } \\
(\%)\end{array}$} & \multirow{2}{*}{$\begin{array}{l}\text { Pellet } \\
\text { Integrity }\end{array}$} & \multirow{2}{*}{ Microstructure } \\
\hline & & $\mathrm{UO}_{2}(\%)$ & $\mathrm{ThO}_{2}(\%)$ & & & & & & & & \\
\hline MGT-103 & $S P-18-1$ & 21.74 & 78.26 & 345 & 34.3 & 76.9 & & 17.8 & 30.4 & Cracked & $\begin{array}{l}\text { Remnant spheres and shards, } \\
\text { internal cracks. }\end{array}$ \\
\hline MGT-104 & $S P-22-1$ & 20.12 & 79.88 & 345 & 40.1 & 90.2 & 97.1 & 8.0 & 26.9 & Good & Internal cracks, voids. \\
\hline Th-U-3.84 & $\mathrm{SP}-28-1$ & 12.09 & 87.91 & 345 & 41.5 & & & 9.9 & 24.8 & Cracked & $\begin{array}{l}\text { Remnant spheres and shards, } \\
\text { internal cracks. }\end{array}$ \\
\hline MGT-111 & $S P-41-1$ & 0 & 100 & 345 & 39.9 & 73.7 & & 10.4 & 22.3 & Cracked & $\begin{array}{l}\text { Remnant spheres and shards, } \\
\text { internal cracks. }\end{array}$ \\
\hline MGT-127 & $S P-41-2$ & 14.43 & 85.57 & 276 & 40.6 & 89.1 & & 8.4 & 26.2 & Good & $\begin{array}{l}\text { Remnant spheres and shards, } \\
\text { internal cracks. }\end{array}$ \\
\hline GT -484 & SP-41-4 & 25.91 & 74.09 & 345 & 44.3 & 75.3 & & 5.5 & 18.2 & Crumbly & $\begin{array}{l}\text { Remnant spheres and shards, } \\
\text { internal cracks. }\end{array}$ \\
\hline GT-484 & $S P-42-3$ & 25.91 & 74.09 & 276 & 42.2 & 70.9 & & 6.9 & 18.3 & Crumbly & $\begin{array}{l}\text { Remnant spheres and shards, } \\
\text { internal cracks. }\end{array}$ \\
\hline
\end{tabular}

\footnotetext{
a Note: The thoria and mixed thoria-urania batches were not calcined before pressing.
} 
• 


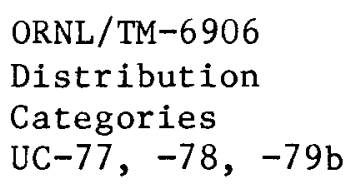

INTERNAL DISTRIBUTION

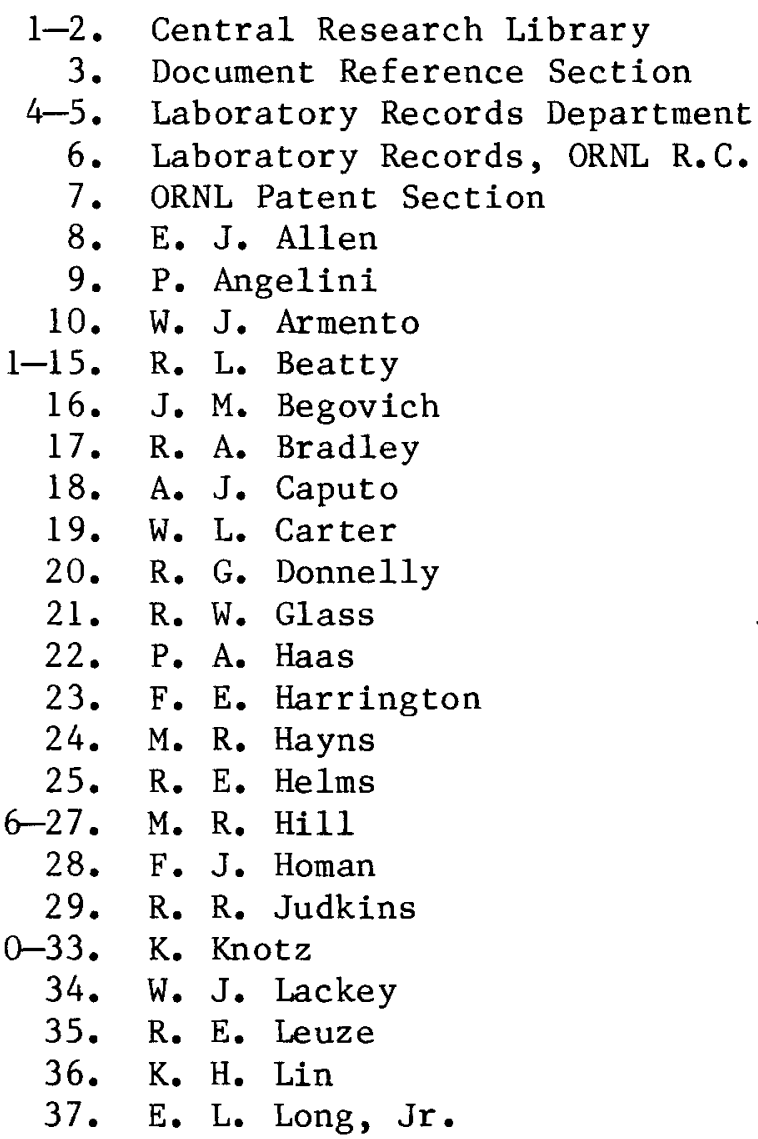

38. A. L. Lotts

39. J. E. Mack

40. M. M. Martin

41. D. L. McElroy

42. A. D. Mitchel1

43. R. E. Norman

44. A. R. O1sen

45. R. L. Pearson

46. A. E. Pasto

47. A. D. Ryon

48. R. D. Spence

49. I. Spiewak

50. D. P. Stinton

51. R. R. Suchomel

52-61. S. M. Tiegs

62. T. N. Tiegs

63. J. S. Vavruska

64. S. K. Whattey

65. D. F. Williams

66. L. C. Williams

67. R. G. Wymer

68. R. W. Balluffi (Consultant)

69. A. L. Bement (Consultant)

70. W. R. Hibbard, Jr. (Consultant)

71. E. H. Kottcamp, Jr. (Consultant)

72. M. J. Mayfield (Consultant)

73. J. T. Stringer (Consultant)

EXTERNAL DISTRIBUTION

74. DOE CHICAGO OPERATIONS OFFICE, 9800 South Cass Avenue, Argonne, IL 60439

Manager

75-76. DOE DIVISION OF NUCLEAR POWER DEVELOPMENT, Washington, DC 20545

Director

77-78. DOE DIVISION OF REACTOR RESEARCH AND TECHNOLOGY, Washington, DC 20545

Director 
79. DOE FAST FLUX TEST FACILITY PROJECT OFFICE, P.0. Box 550, Richland, WA 99352

\section{Director}

80-129. FUEL REFABRICATION AND DEVELOPMENT PROGRAM OFFICE, Battelle Pacific Northwest Laboratories, P.0. Box 999, Richland, WA 99352

130. DOE RICHLAND OPERATIONS OFFICE, P.0. Box 550, Richland, WA 99352 Manager

131. SAN-DEVElopMent, SAN DIEgo AREA OFFICE, P.0. Box 81325, San Diego, CA 92138

Senior Program Coordinator

132. DOE SAN FRANCISCO OPERATIONS OFFICE, 1333 Broadway, Wells Fargo Building, Oakland, CA 94612

Manager

133. DOE OAK RIDGE OPERATIONS OFFICE, P.O. BOX E, Oak Ridge, TN 37830 Assistant Manager, Energy Research and Development

134-512. DOE TECHNICAL INFORMATION CENTER, P.0. Box 62, Oak Ridge, TN 37830

For distribution as shown in TID-4500 Distribution Category, UC-77 (Gas-Cooled Reactor Technology), UC-78 (Light Water Reactor Technology), and UC-79b (LMFBR - Fuels and Materials Engineering and Development). 